\title{
DISAGREEMENT, SPECULATION AND MANAGEMENT FORECASTS
}

\author{
Valentin Dimitrov ${ }^{\mathrm{a}}$, Darius Palia ${ }^{\mathrm{a}, \mathrm{b}}$ and Zhiwei $\mathrm{Xu}^{\mathrm{a}}$
}

\begin{abstract}
Prior theoretical and empirical research has shown that disagreement can cause speculative trading which leads to a speculative premium in stock prices. We examine whether managers take actions to reduce or prolong the disagreement among investors. We establish causality using the exogenous variation in speculative trading after the yearly reconstitution of the Russell 1000/2000 indices. We find that speculative trading reduces the frequency, likelihood, and precision of management forecasts. This relationship is significantly stronger when short-sale constraints are more binding. Consistent with theory, the effect is more pronounced when managers have stronger equity-based incentives. We also find that managers sell equity to benefit from the speculative premium. In summary, our results suggest that managers issue forecasts opportunistically in response to speculative trading - they keep silent whenever possible, and issue fewer and less precise forecasts to prolong disagreement and overpricing.
\end{abstract}

(JEL C50, G12, G14, M41)

\footnotetext{
${ }^{a}$ Rutgers Business School and ${ }^{b}$ Columbia Law School, respectively. We thank Michael Carniol, Yiwei Dou, Feng Gao, Suresh Governdraj, Bikki Jaggi, Bharat Sarath and seminar participants at Rutgers Business School for helpful discussions and comments. All errors remain our responsibility. Corresponding author: Darius Palia; dpalia@business.rutgers.edu.
} 


\section{DISAGREEMENT, SPECULATION AND MANAGEMENT FORECASTS}

\section{Introduction}

A large financial economics literature beginning with Miller (1977), Harrison and Kreps (1978), and Scheinkman and Xiong (2003) has suggested that heterogeneous beliefs ${ }^{1}$ among investors can lead to speculative trading (or speculation) and to share prices that exceed fundamental value. ${ }^{2}$ This speculative premium, or overvaluation, may not be arbitraged away due to market frictions such as short-sale constraints, noise-trader risk or capital constraints (see Xiong (2013) for an excellent survey). Empirical studies find strong support for the prediction that heterogeneous beliefs lead to overvaluation (see, for e.g., Deither, Malloy, and Scherbina, 2002; Chen, Hong and Stein, 2002; Geszy, Musto and Reed, 2002; Lamont and Thaler, 2003; Ofek and Richardson, 2003; Hong and Stein, 2003; Nagel, 2005; Bris, Goetzman and Zhu, 2007; Chang, Cheng and Yu, 2007; Xiong and Yu, 2011; and Pan et al., 2015).

Prior literature suggests that managers benefit from overvalued equity because of the increase in their firm-related wealth (Jensen, 2005). This can incentivize managers to take actions to boost the current stock price at the expense of long-term value (Graham, Harvey and Rajgopal, 2005; Bolton, Scheinkman and Xiong, 2006). Issuing management forecasts is a flexible and effective strategy for managers to influence the disagreement among investors. Both Harrison and Kreps (1978) and Scheinkman and Xiong (2003) highlight that fundamentals are the primary

\footnotetext{
${ }^{1}$ We use heterogeneous beliefs, differences of opinion, and disagreement interchangeably.

${ }^{2}$ Other theoretical papers include De Long, et al. (1990), Harris and Raviv (1993), Kandel and Pearson (1995), Morris (1996), Kyle and Wang (1997), Shleifer and Vishny (1997), Odean (1998), Duffie, Garleanu and Pedersen (2002), Bolton, Scheinkman and Xiong (2005), Hong, Scheinkman and Xiong (2006). See Section II for more comprehensive and detailed explanation of the various papers.
} 
source of disagreement among investors. Management forecasts are informative about fundamentals and can alter investors' beliefs. Importantly, managers have discretion over the frequency and content of management forecasts. ${ }^{3}$

This paper examines whether managers issue forecasts opportunistically in response to speculative trading. Specifically, we test whether there is a causal relationship from speculation to disclosure. Speculation is an endogenous variable. Management disclosures may induce speculation by exacerbating the disagreement between investors who interpret the same public signal differently (e.g., Harris and Raviv, 1993; Kandel and Pearson, 1995). In this case, causality is in the opposite direction, from disclosure to speculation. Similarly, the association between speculation and management forecasts may be driven by some common but unobservable factors. For example, if macroeconomic uncertainty increases, it may increase speculation regarding the firms' prospects while also motivating managers to make more disclosures to reduce that uncertainty. ${ }^{4}$

We address this endogeneity concern by using the assignment of firms to the Russell $1000 / 2000$ index as an instrument for speculative trading. Firms around the Russell 1000/2000 cutoff are unable to manipulate their assignment, and these firms' inclusion in either Russell 1000 or Russell 2000 can be treated as a random event. Because the Russell indices are value-weighted, the largest firms in Russell 2000 have significantly greater weights than the smallest firms in Russell 1000. ${ }^{5}$ In turn, institutional investors who track or benchmark their performance to these

\footnotetext{
3 There is a rich literature in accounting showing that management forecasts are informative. See, for e.g., Penman, (1983, 1985); Lev and Penman (1990); Bergman and Roychowdhury (2008); Beyer et al., (2010); Seybert and Yang (2012).

${ }^{4}$ As yet another example, a new product launch may lead investors to speculate on its success while at the same time requiring additional disclosures by managers regarding future incremental sales and earnings.

${ }^{5}$ For example, the 800th through 1,000th largest stocks have relatively small weights within Russell 1000 since they are the smallest firms in the index, while the firms ranked from $1,001^{\text {st }}$ to $1,200^{\text {th }}$ have relatively large weights in Russell 2000 since they are the largest firms in the index.
} 
indices hold greater positions in the largest stocks in Russell 2000 than in the smallest stocks in Russell 1000 (Boone and White, 2015; Appel et al., 2016; Bird and Karolyi, 2016, 2017; Crane et al., 2016; Khan et al., 2017; Chen et al, 2018). Greater passive institutional ownership in the largest stocks in Russell 2000 reduces trading costs to speculators. It may also create more speculative trading opportunities when passive investors trade in response to fund flows or to rebalance their portfolios. Both effects are likely to increase speculative trading in the largest stocks in Russell 2000 relative to the smallest stocks in Russell 1000. Consistent with these arguments, we find that our proxy for speculation is significantly greater for firms in the top of Russell 2000 than firms in the bottom of Russell $1000 .^{6}$

The empirical literature relies on trading volume and volume-based measures such as share turnover to measure speculative trading (e.g., Harris and Raviv,1993; Bamber et al., 1999; Berkman et al., 2009). However, trading volume also reflects liquidity trades or rebalancing needs (e.g., Hong and Stein, 2007). We use nine proxies of differences of opinion to identify the part of share turnover driven by disagreement using the three-pass regression filter (3PRF) of Kelly and Pruitt (2015). This is the measure of speculative trading used in the paper. We use institutional ownership as a proxy for short-sale constraints (Nagel, 2005; Asquith, Pathak and Ritter, 2005; Berkman et al., 2009). Using data from 1996 to 2006 for Russell 3000 firms, we find that speculative trading reduces the frequency, likelihood, and precision of management forecasts. In addition, we find that the relationship between speculative trading and the frequency, probability, and precision of management forecasts is significantly stronger (i.e., more negative) when shortsale constraints are more binding. Our results suggest that managers issue forecasts

\footnotetext{
${ }^{6}$ See Section III for a detailed explanation of this methodology.
} 
opportunistically in response to speculative trading - they keep silent whenever possible, and issue fewer and less precise forecasts to prolong disagreement and overpricing.

To support the primary results, we test one important channel through which speculation may affect management forecasts. Bolton et al. (2005) argue that in speculative markets, shareholders incentivize managers to boost the current stock price by tilting their compensation towards stock and stock option grants. When managers have stronger equity-based incentives, their wealth is more sensitive to the stock price which includes the speculative premium. As a result, managers with greater equity incentives have greater incentives to issue management forecasts opportunistically in response to speculation. Consistent with this prediction, we find that the effect of speculation on management forecast activity is more pronounced when managers have stronger equity-based incentives. We also find that managers are more likely to sell their shares in response to greater speculation, consistent with our prediction that managers trade to take advantage of the resulting price.

In additional tests, we find that managers are more likely to cater to optimistic investors when there is greater speculation and more binding short-sale constraints. We analyze Regulation SHO that relaxes short-sale constraints for a randomly chosen sample of Russell 3000 firms. We find that our main results hold using Regulation SHO to determine whether short-sale constraints are relatively binding or not. A key assumption in our study is that management forecasts reduce speculative trading by decreasing disagreement. Consistent with this assumption, we find that the three-day cumulative excess returns around management forecast dates become smaller when there is greater speculation and more binding short-sale constraints. We also show that the main results are robust to controlling for contemporaneous analyst coverage and to using ranks based on market 
values at the end of May rather than index weights to determine the firms around the Russell 1000/2000 threshold.

We make the following contributions to the extant literature. First, we show that speculation driven by heterogeneous beliefs has a causal effect on management's voluntary disclosure policy. Our results are consistent with managers taking actions to maintain or prolong the speculative premium in prices (Jensen, 2005; Bolton et al., 2006). Second, we extend the literature on the effects of stock prices on managers behavior. Prior literature has shown that overvaluation leads to higher investments, greater reliance on external financing, and earnings management (e.g., Gilchrist et al., 2005; Chi and Gupta, 2009; Polk and Sapienza, 2009; Warasawitharana and Whited, 2016). We show that managers also alter their disclosure policy to prolong the overvaluation. Third, we construct a new, less noisy measure of speculation using the three-pass regression filter of Kelly and Pruitt (2015). Researchers can use this measure to test other hypotheses related to speculation.

This paper proceeds as follows. Section II reviews the related literature. Section III describes our measure of speculative trading, identification strategy, and data and sample selection. Section IV describes our main empirical results. Section V discusses the results of several additional tests. Section VI presents our conclusions.

\section{Literature Review}

Kaldor (1939) defines speculation as "the purchase (or sale) of goods with a view to resale (repurchase) at a later date, where the motive behind such action is the expectation of a change in the relevant prices relatively to the ruling price". Prior research suggests that speculation driven by disagreement influences stock prices. With binding short-sale constraints, investors may overpay for a stock relative to their own valuation of future dividends because of 
the embedded option to sell the shares at an even higher price in the future (e.g., Harrison and Kreps, 1978; Morris, 1996; Scheinkman and Xiong, 2003). Stock ownership provides an option to reap speculative profit from other investors with more optimistic beliefs. Hence, in a stock market where investors disagree about a firm's valuation and short-sale constraints are binding, speculative bubbles may arise. Importantly, Scheinkman and Xiong (2003) show that the resulting speculative bubble is associated with greater speculative trading. The theory is supported by empirical studies that show that disagreement and speculative trading are negatively correlated with future excess returns (e.g., Deither, Malloy, and Scherbina, 2002; Chen, Hong and Stein, 2002; Lamont and Thaler, 2003; Hong and Stein, 2003; Bris, Goetzman and Zhu, 2007; Boehme et al, 2006; Chang, Cheng and Yu, 2007; Chen, Lung and Wang,2009; Mei, Scheinkman and Xiong, 2009; Xiong and Yu, 2011; Pan et al., 2015). The theory is also supported by Palfrey and Wang (2012) and Fellner and Theissen (2014), who show that speculation and short-sale constraints lead to overpricing in a laboratory setting.

Speculation may also lead to greater trading risk (e.g., Varian, 1989; David, 2008; Carlin et al., 2014). David (2008) suggests that investors with heterogeneous beliefs speculate on the relative accuracy of their models' forecasts and face the risk that stock prices move in line with the trading models of other speculators. Carlin et al. (2014) argue that speculators face both fundamental risk and risk that their beliefs about others are incorrect. This additional risk may lead risk-averse investors to require a higher rate of return (risk premium) for holding more speculative stocks and thereby may result in lower stock prices. This theory has some empirical support (Anderson et al., 2005; Garfinkel and Sokobin, 2006; Doukas et al. 2006; Carlin et al. 2014). The risk premium effect is more likely to be evident when short-sale constraints are not binding and there is no speculative premium. 
Given that managers have incentives to maximize their companies' stock price, they may take actions in response to speculation. We posit that one way for managers to influence the stock price is by making selective voluntary disclosures such as management forecasts (e.g., Bergman and Roychowdhury, 2008; Seybert and Yang, 2012; Li and Zhang, 2015). Management forecasts are informative to investors. Beyer et al. (2010) show that management forecasts explain 15.67\% of quarterly stock return variance during the sample period from 1994 to 2007, accounting for 55\% of the total return variances explained by the five types of disclosure they study. ${ }^{7}$ Importantly, management forecasts can reduce uncertainty and heterogeneity in beliefs about future earnings (e.g., Baginski et al., 1993; Bergman and Roychowdhury, 2008). Moreover, forecasts provide managers the flexibility to choose the characteristics of the information release, such as the frequency, form, horizon and timing (e.g., Healy and Palepu, 2001; Beyer et al., 2010).

One plausible management strategy to prolong speculative premium is to reduce the amount of information provided to investors. Previous research suggests that there are equilibria where managers disclose favorable information but withhold unfavorable information to maximize stock price ${ }^{8}$ Favorable news can become unfavorable when the stock price is inflated. Hence, managers may voluntarily disclose less information when stock prices are inflated. For example, Bergman and Roychowdhury (2008) show that managers issue fewer long-horizon management forecasts in high sentiment period and issue more management forecasts in low sentiment period. Moreover, disclosing more information may directly reduce uncertainty and disagreement among investors and further decrease speculative premium (Dorobantu, 2006). Consequently, we expect managers to issue fewer forecasts in response to greater speculative trading.

\footnotetext{
${ }^{7}$ These include management forecasts, earnings announcements, earnings pre-announcements, analyst forecasts, and SEC filings.

${ }^{8}$ The conditions for partial disclosure are (1) there are proprietary costs for voluntary disclosure (Verrecchia, 1983, 2001); and (2) investors are uncertain whether a manager is informed (Dye, 1985).
} 
The strategy of nondisclosure is not always feasible when managers are subject to litigation and reputation costs (e.g., Skinner, 1994). An alternative strategy is for managers to reduce the precision of their management forecasts. Prior literature shows that a management forecast that is more precise is associated with stronger market reaction and greater informativeness (e.g., Baginski et al., 1993). Managers often choose the precision of their earnings forecasts to influence investors' perceptions and in turn stock prices. Cheng et al. (2013) find that prior to insider sales (purchases), managers increase (decrease) the precision of their earnings forecasts when the news is positive and decrease (increase) precision of earnings forecasts when the news is negative. $\mathrm{Li}$ and Zhang (2015) find that managers reduce the precision of bad news forecasts in response to increased short selling pressure. Hertzberg (2017) analytically show that managers can commit to making less precise disclosures to exacerbate disagreement and prolong the speculative premium. Consequently, we expect managers to issue forecasts that are less precise in response to greater speculative trading.

\section{Data and Research Design}

\section{A. Measuring speculative trading}

This section discusses how we construct our measure for speculative trading. Prior research most commonly measures speculation as either turnover or trading volume. However, turnover and trading volume also capture other information that is not directly related to investor speculation, such as liquidity demand and portfolio rebalancing. The resulting noise may distort the empirical tests. To alleviate this issue, we isolate disagreement-based turnover from total turnover. We adopt the three-pass regression filter (3PRF) of Kelly and Pruitt (2015) to aggregate the information about heterogeneous beliefs embedded in several variables. Although Kelly and 
Pruitt (2015) originally develop this model for time series forecasting, Rytchkov et al. (2017) extend it to forecast variables in the cross-section of firms.

The first step of 3PRF is to construct a linear factor model in which turnover is driven by the latent factor, namely heterogeneous beliefs. The factor model we choose is motived by the "Notrade theorem" (e.g., Tirole, 1982; Milgrom and Stokey, 1982; Morris, 1995). For trading to occur, investors must have either heterogeneous beliefs or liquidity, diversification, or portfolio rebalancing needs (e.g., Scheinkman and Xiong, 2003; Biais and Bossaerts, 1998; Xiong, 2013). We express the factor model as:

$$
\operatorname{TURN}_{t, i}=\alpha_{t}+\beta_{t} H B_{t, i}+\varepsilon_{t, i}
$$

where TURN is share turnover and $H B_{t, i}$ is heterogeneous beliefs for firm $i$ in month $t .^{9}$ The key assumptions for this model are that heterogeneous beliefs are uncorrelated with non-speculative demand for trading and that current heterogeneous beliefs capture past heterogeneous beliefs. Heterogeneous beliefs in prior periods can be thought of as heterogeneous priors, which are included in the current period heterogeneous beliefs. Namely,

$$
E\left(\text { Turnover }_{t, i} \mid H B_{t, i}\right)=E\left(\text { Turnover }_{t, i} \mid H B_{t, i}, H B_{t-1, i}, \ldots, H B_{t-n, i}\right)
$$

We then select proxies for heterogeneous beliefs that satisfy the following factor structure:

$$
\operatorname{Proxy}_{t, i}=\theta_{t}+\varphi_{t} H B_{t, i}+v_{t, i}
$$

The nine proxies commonly used in the empirical literature include the volatility of excess returns $(\mathrm{Vol})$, bid-ask spread (Spread), unexpected volume (ASUV), dispersion of analyst earnings forecasts scaled by stock price or the mean analyst forecast (ADISP1, ADISP2), volume-weighted

\footnotetext{
${ }^{9}$ We define heterogeneous beliefs to encompass heterogeneous priors, heterogeneous interpretation, or heterogeneous information precision.
} 
option strike dispersions and open-interest-weighted option strike dispersions (ODISP1, ODISP2), open interest $(O I)$, and option trading volume $(O V) .{ }^{10}$ These variables are constructed using stock price data, analyst data, and options data. Stock price data and options data primarily capture disagreement about valuations (prices) and analyst data primarily captures disagreement about fundamentals. Appendix A shows the construction of each variable. All variables are winsorized at the $1 \%$ and the $99 \%$ level and then standardized to have a mean of zero and variance of one. Table 1 shows the summary statistics of TURN and the nine proxies before they are standardized. The sample contains Russell 3000 firms, from January 1996 to September 2006 due to the availability of Russell reconstitution data.

\section{[Insert Table 1 Here]}

The next step is to run cross-sectional regressions of TURN on each of the nine proxies individually for each calendar month from Jan 1996 to Jan 2007. For each month, we estimate nine slopes, one for each proxy, which we denote as $\mu_{\mathrm{j}}, \mathrm{j}=1,2, \ldots 9$. Then for each firm and each month, we regress proxy $y_{j}$ on $\mu_{j}$ conditional on having at least five observations. The slope from each regression is the estimated value of heterogeneous beliefs, noted as $\widehat{H B}_{i, t}{ }^{11}$ According to Proposition 1 (page 1348) in Light, Maslov, and Rytchkov (2017), $\widehat{H B}_{i, t}$ converges to the true value of heterogeneity of beliefs scaled by $\beta_{t} \operatorname{Var}\left(H B_{i, t}\right)$. Namely,

$$
\widehat{H B}_{i, t} \stackrel{p}{\rightarrow} \frac{H B_{i, t}}{\beta_{t} \operatorname{Var}\left(H B_{i, t}\right)}
$$

where $\operatorname{Var}\left(H B_{i, t}\right)$ is a constant but $\beta$ may be time-varying.

\footnotetext{
${ }^{10}$ See Bessembinder et al., 1996; Dieither et al., 2004; Boehme et al., 2006; Buraschi and Jiltsov, 2006; Garfinkel and Sokobin, 2006; Berkman et al., 2009; Garfinkel, 2009; Friesen et al., 2012; Zhu., 2015.

${ }^{11}$ For additional assumptions of 3PRF, please refer to Assumption 2 through 6 in Kelly and Pruitt (2015), p296, and Assumption 1 through 4 in Light, Maslov, and Rytchkov (2017), p1345-1346.
} 
In the final step, we estimate cross-sectional regressions of $T U R N_{i, t}$ on $\widehat{H B}_{i, t}$ for each month to obtain the fitted value for each firm. Theorem 1 in Kelly and Pruitt (2015) indicates:

$$
\widehat{T U R N}_{i, t} \stackrel{p}{\rightarrow} \alpha_{i}+\beta_{1, t} H B_{t, i}=E\left(\text { Turnover }_{t, i} \mid H B_{t, i}\right)
$$

That is, the fitted turnover converges to the expected turnover due to heterogeneous beliefs. The fitted turnover $\left(\widehat{T U R N}_{i, t}\right)$ is our proxy for speculation $(S P T)$, and it is estimated at the monthly level for each Russell 3000 firm. We average the adjusted $R^{2} s$ in all years from 1996 to 2006 and find that the fitted turnover explains about $40 \%$ of the total turnover.

Eq. (6) shows the relationship between the proxy for disagreement-based speculation (SPT) and the nine proxies for heterogeneous beliefs. Specifically, we regress $S P T$ on the nine proxies to obtain the following coefficients:

$$
\begin{aligned}
& \widehat{\mathrm{PT}}=0.106+0.269 \mathrm{VOL}+0.552 \mathrm{SPREAD}+0.193 \mathrm{ASUV}+0.1100 \mathrm{DISP} 1+ \\
& +0.1690 \mathrm{DISP} 2-0.099 \mathrm{ADISP} 1-0.124 \mathrm{ADISP} 2+0.0740 \mathrm{~V}-0.0180 \mathrm{I}
\end{aligned}
$$

According to Eq. (6), the bid-ask spread (SPREAD), volatility of excess returns (VOL) and unexpected trading volume $(A S U V)$ are the three most important components in $S P T$. Open interest $(O I)$ and option trading volume $(O V)$ contribute little to $S P T$. The coefficients on the two dispersions of analysts' forecasts are negative. This might be due to analysts' herding behavior. When faced with great information uncertainty, analysts often imitate the consensus forecast in their forecasts (e.g., Huang et al., 2017), reducing the dispersion of analyst forecasts.

\section{B. Russell index reconstitution and instrumental variables}

We address the endogeneity of speculative trading by using the reconstitutions of Russell 1000 and Russell 2000 indices. Russell 1000 and 2000 indices are annually reconstituted using a mechanical method that is publicly known in advance. FTSE Russell ranks all listed US firms according to their market values, determined by the closing price on the last trading day of May 
and the total common shares outstanding as adjusted by FTSE Russell. The first 1000 firms constitute the Russell 1000 index while the next 2000 firms constitute the Russell 2000 index. If a firm has multiple classes of stock, then FTSE Russell uses the class with the largest float (Crane et al., 2015). Although FTSE Russell determines index composition using public market values at the end of May, index weights are determined at the end of June using FTSE imputed market values. Because a firm's index assignment depends on its market value rank, whether a firm around the market value threshold of Russell 1000 is assigned to Russell 1000 or Russell 2000 is not known ex-ante. As a result, firms around the threshold are unable to ensure their inclusion in Russell 1000 or predict precisely which index they get assigned to. In other words, the Russell 1000/Russell 2000 assignment around the threshold is locally random (e.g., Boone and White, 2015; Crane et al., 2015; Appel et al., 2016; Bird and Karolyi, 2016, 2017; Khan et al., 2017; Chen et al. 2018).

Whether a firm is assigned to Russell 1000 or Russell 2000 has implications for its ownership structure, and in turn for speculative trading. Because the Russell indices are value-weighted, the largest firms in the Russell 2000 have significantly greater index weights than the smallest firms in the Russell 1000. Institutional investors who track or benchmark their performance to these indices must buy proportionately more shares in firms at the top of Russell 2000 than in firms at the bottom of Russell 1000 after FTSE Russell announces the reconstituted indices. The firms at the top of Russell 2000 attract more institutional investors (e.g., Boone and White, 2015; Crane et al., 2016; Khan et al., 2017). This, in turn, can affect speculation. Institutions tracking the Russell indices trade in response to investor fund flows or rebalancing needs, leading to lower trading costs and more trading opportunities in these stocks. The increased trading opportunities attract 
speculators to enter the market. ${ }^{12}$ Hence, index inclusion around the threshold is likely to be a suitable instrument for speculation. We test the relevance of this instrumental variables approach in Section IV.

FTSE Russell uses confidential data to adjust shares outstanding and compute market values at the end of May, but does not provide details on its methodology. This makes it impossible to identify firms around the threshold precisely. Previous studies propose two methods to deal with this issue. The first method is to approximate each firm's market value at the end of May with data from CRSP and Compustat and then to rank the firms accordingly (e.g., Chang et al., 2015; Crane et al.,2015; Bird and Karolyi, 2017). The second method is to use index assignments and weights from data provided by FTSE Russell (e.g., Boone and White, 2015; Appel et al., 2016; Khan et al. 2017; Chen et al., 2018). The data from FTSE Russell contains a binary variable that labels the actual index assignment for each firm and the ranks of firms based on index weights at the end of June.

We use the second method to rank our firms around the threshold. The advantage of using Russell's actual index assignment data is it avoids the measurement error problem for binary variables. The ranking based on the market capitalization calculated with data from CRSP or Compustat can be quite different from the exact rank set by FTSE Russell. It is possible that some firms that should have been classified into Russell 2000 are misclassified into Russell 1000, and vice versa. This measurement error could lead to inconsistent estimation. ${ }^{13}$

\footnotetext{
${ }^{12}$ To illustrate, suppose at $\mathrm{T}=1$ speculator $\mathrm{A}$ wants to purchase a stock at $\$ 5$ per share but investor B, who currently holds the stock, is only willing to sell it at $\$ 6$ per share. As a result, A will not be in the market. Suppose at $\mathrm{T}=2$, another speculator, $\mathrm{C}$, wants to purchase the same stock at $\$ 5.5$ per share. There will still be no trade because B's asking price has not been met. However, if at $\mathrm{T}=1$ investor $\mathrm{B}$ is an institution faced with redemptions and has to sell the shares, speculator A can purchase it at $\$ 5$ per share at $\mathrm{T}=1$ and resell it at $\$ 5.5$ per share to speculator $\mathrm{C}$ at $\mathrm{T}=2$.

${ }^{13}$ We show in Section V that our results are similar if we use the identification strategy of Crane et al. (2015) to construct the bandwidths around the Russell 1000/2000 threshold.
} 
One potential concern of using index assignment as an instrument for the proxy for speculation is that index assignment is also correlated with institutional ownership (e.g., Boone and White, 2015; Crane et al., 2015; Bird and Karolyi, 2016). Institutional ownership may affect management's voluntary disclosures directly (e.g., Boone and White, 2015). We alleviate this concern by including institutional ownership as a control variable in our model. This method is referred to as a conditional instrumental variable estimation (see, for e.g., Morgan and Winship, 2007). Another reason for including institutional ownership in the model is that institutional ownership is a commonly used proxy for short-sale constraints (e.g., Nagel, 2003; Asquith et al., 2005; Berkman et al., 2009). Institutions are the main suppliers of shares to short sellers; when institutional ownership is low, it is more difficult and costly for short sellers to borrow the shares (e.g., Prado et al., 2016). Because institutional ownership is likely endogenous to disclosure policy (e.g., Boone and White, 2015), we also instrument institutional ownership for each firm using the average institutional ownership of other firms across different periods in the sample. Appendix B provides details on this approach.

\section{Sample and data}

The sample consists of Russell 3000 index constituents from 1996 to $2006 .{ }^{14}$ FTSE Russell did not provide us Russell membership data prior to 1996. The sample ends in 2006 because after 2006 FTSE Russell no longer determines index assignments based only on market values at the end of May. Hence, the local randomization around the threshold may no longer hold after 2006. We merge the Russell data with institutional holding data from Spectrum 13F, stock data from CRSP, and firm-level accounting data from Compustat. We obtain management forecasts data and

\footnotetext{
${ }^{14}$ We thank FTSE Russell Inc. for providing these data.
} 
analyst forecasts data from $\mathrm{I} / \mathrm{B} / \mathrm{E} / \mathrm{S}$ and equity-based compensation data from ExecuComp. The final sample includes 6,480 firms and 32,977 firm-year observations.

The primary independent variables are SPT, derived using 3PRF as described in Section III.A, and institutional ownership (INST). Similar to SPT, we standardize INST to have a mean of zero and a standard deviation of one. This mitigates any mechanical correlation between SPT and SPT $\times I N S T$. SPT is measured in September (two months after reconstitution). We choose September because this is the first month after reconstitution with available institutional ownership data. ${ }^{15}$ Table 2 reports the summary statistics of the variables used in the subsequent tests, separately for Russell 1000 and Russell 2000 firms. The mean and median of SPT are higher for Russell 1000 firms than for Russell 2000 firms. The mean frequency of management forecasts is also higher for Russell 1000 firms than for Russell 2000 firms. The mean precision of earnings forecasts is similar for both Russell 1000 firms and Russell 2000 firms. The mean institutional ownership is 0.64 for Russell 1000 firms and 0.53 for Russell 2000 firms, similar to the result of Crane et al. (2016).

\section{[Insert Table 2 Here]}

\section{Estimation model}

We test how speculation affects management forecasts within a small bandwidth $(200,250$, 300 firms) around the Russell 1000/2000 threshold. We adopt a two-stage model to estimate the relationship between the dependent variable (i.e., properties of management forecasts) and the variables of interest (speculative trading, institutional ownership, and their interaction). Since properties of management forecasts include count data (frequency of management forecasts) and

\footnotetext{
${ }^{15}$ Institutional ownership data are made public at the end of each calendar quarter. Our results are similar if we use the average $S P T$ of July, August, and September.
} 
binomial data (likelihood of a management forecast), we use a Logit regression and a Poisson regression, respectively. We use the control function approach to estimate our models (e.g., Woodridge, 2002, 2015; Marra and Radice, 2011).16 The two-stage model is specified as follows:

$$
\begin{aligned}
& S P T_{i, t}=a_{1}+\alpha_{2} R 2000_{i, t}+\alpha_{3} \text { Rank }_{i, t}+\alpha_{4} L_{n M V_{i, t}}+\alpha_{5} \text { Float }_{i, t}+\alpha_{6} \operatorname{Ret}_{i, t}+\sum y e a r+\epsilon_{i, 1}(7) \\
& \text { INST }_{i, t}=\beta_{1}+\beta_{2} \text { IVinst }_{i}+\beta_{3} \text { Rank }_{i, t}+\beta_{4} \text { LnMV }_{i, t}+\beta_{5} \text { Float }_{i, t}+\beta_{6} \text { Ret }_{i, t}+\sum y e a r+\epsilon_{i, 2} \\
& S P T \times I N S T_{i, t}=\gamma_{1}+\gamma_{2} R 2000 \times \text { IVinst }_{i, t}+\gamma_{3} \text { Rank }_{i, t}+\gamma_{4} \text { LnMV }_{i, t}+\gamma_{5} \text { Float }_{i, t} \\
& +\gamma_{6} \operatorname{Ret}_{i, t}+\sum \text { year }+\epsilon_{i, 3} \\
& \text { FORECAST }_{i, t+1}=\theta_{1}+\theta_{2} S P T_{i, t}+\theta_{3} I N S T \times S P T_{i, t}+\theta_{4} I N S T_{i, t}+\theta_{5} \operatorname{Rank}_{i, t}+\theta_{6} \operatorname{LnMV}_{i, t}+ \\
& \theta_{7} \text { Float }_{i, t}+\theta_{8} \text { Ret }_{i, t}+\theta_{9} \hat{\epsilon}_{1, i}+\theta_{10} \hat{\epsilon}_{2, i}+\theta_{11} \hat{\epsilon}_{3, i}+\sum \text { year }+v_{i, t}
\end{aligned}
$$

In the first stage, we estimate Eq. (7), (8) and (9) via OLS and obtain the residual from each equation. Equation (7) is equivalent to a sharp regression discontinuity regression (RDD) with a binary treatment variable, R2000, which equals 1 for firms assigned to Russell 2000 and 0 for firms assigned to Russell 1000. We use Eq. (7) to isolate the endogenous component of SPT. Equation (8) isolates the endogenous component of institutional ownership. IVinst ${ }_{i}$ is our instrument for $\mathrm{INST}_{\mathrm{i}, \mathrm{t}}$ as explained in Appendix B. Equation (9) isolates the endogenous part of the interaction of SPT with INST. Following Crane et al. (2015), we control for the difference between the rank based on the market values at the end of May and the rank based on the weights assigned by FTSE Russell (Float). This captures the change in index weights due to float adjustment of FTSE Russell at the end of June. We control for the logarithm of market value at the end of May calculated using CRSP data (LnMV). ${ }^{17}$

\footnotetext{
${ }^{16} 2 \mathrm{SLS}$ is not valid for nonlinear models. For a linear model, 2SLS and the control function approach generate the same estimation results. However, the control function approach can also be used to estimate nonlinear and nonparametric models (e.g., Marra and Radice, 2011).

${ }^{17}$ Our results are similar if we include additional control variables, including $R O A$, Market to Book ratio $(M B)$, Leverage (Lev), volatility of cash flow (Stdocf), capital expenditure (Invest), cash flow from financing (Finance), revenue growth (Growth), Big4 auditors (Big4), probability of informed trading (PIN), liquidity (Liqudity) and litigation (litigation). Variable definitions are reported in Appendix A.
} 
In the second-stage regression given by Eq. (10), we estimate the effect of speculation on several dependent variables after controlling for the residuals from the first stage $\left(\hat{\epsilon}_{1, \mathrm{i}}, \hat{\epsilon}_{2, \mathrm{i}}, \hat{\epsilon}_{3, \mathrm{i}}\right)$. The second stage also includes the firm's stock return in September. This controls for any contemporaneous news and private information contained in price that in turn affects management's voluntary disclosure policy.

\section{Tests and Results}

\section{A. Instrumental variables}

In this section, we examine the relevance assumption of the instruments for speculation and institutional ownership. The bandwidth selection around the Russell 1000/2000 reconstitution threshold involves a trade-off between variance and bias. As the bandwidth decreases, the estimates become more accurate but the variances grow. We use three relatively large bandwidths $( \pm 200, \pm 250, \pm 300$ firms from the threshold) to ensure sufficient sample size. Panel A of Table 3 reports estimates of the discontinuity in SPT around the Russell 1000/2000 threshold as given by Eq. (7). We find that index assignment around the cutoff satisfies the relevance assumption of an IV. The results are similar for all three bandwidths. For example, using the 300 bandwidth, the coefficient on $R 2000$ is 0.186 ( $t=4.48)$. This suggests that $S P T$ for firms at the top of Russell 2000 is significantly greater than SPT for firms at the bottom of Russell 1000. Panel B of Table 3 shows the relationship between INST and its instrument, as given by Eq. (8). We find that IVinst is significant for each bandwidth. For example, using the 300 bandwidth, the coefficient on IVinst is $0.65(t=14.28) .{ }^{18}$

\section{[Insert Table 3 Here]}

\footnotetext{
${ }^{18}$ We also find a significant relationship between $S P T * I N S T$ and $R 2000 * I V i n s t$ for each bandwidth, as given by Eq.
} (9). The results are not tabulated for brevity and are available from the authors upon request. 


\section{B. Properties of management forecasts}

We examine three separate characteristics of management forecast - the frequency and likelihood of management forecasts, and their precision. We define $F R E Q$ as the number of management forecasts (number of earnings forecasts plus the the number of sales forecasts for any future quarter or year) during September and October of each respective year. ${ }^{19}$ We only consider management forecasts issued before the corresponding forecast period end date. Forecasts issued after the forecast period end date are preannouncements because managers know the actual numbers. We define $P R O B$ as one if managers issue at least one forecast (quarterly and annually, earnings or sales) during the period, and zero otherwise. Given that the frequency of management forecast is count data, we estimate a Poisson model for FREQ in the second stage regression as given by Eq. (10). ${ }^{20}$ We estimate a Logit model for PROB.

Panel A of Table 4 shows the results for the frequency of management forecasts. We find that $S P T$ is negative and highly statistically significant for all three bandwidths. For example, using the 300 bandwidth, the coefficient on $S P T$ is -3.558 with $t$-stat of -1.94 . When institutional ownership is at its mean (0), managers reduce the frequency of management forecasts in response to speculation. One standard deviation increase in $S P T$ is associated with $2.348 \%$ fewer management forecasts, on average. We also find that $S P T \times I N S T$ is positive and significant for each bandwidth. Using the 300 bandwidth, the coefficient on SPT×INST is 1.125 with $t$-stat of 2.12. This finding shows that as short sales become more binding (i.e., when institutional ownership decreases), managers issue even fewer forecasts in response to greater speculative trading. For example, when institutional ownership is at the fifth percentile, one standard deviation

\footnotetext{
${ }^{19}$ Our results are robust to using alternative windows after reconstitution (4 months, 6 months and 8 months).

${ }^{20} \mathrm{We}$ also estimate a negative binomial model for FREQ and find similar results.
} 
increase in SPT is associated with 3.645\% fewer management forecasts, on average. These findings are consistent with our prediction that managers issue fewer forecasts in response to speculation, especially when short-sale constraints are more binding.

We find similar results using the probability as the dependent variable in Eq. (10). The results are reported in Panel B of Table 4. The coefficient on SPT is negative and highly statistically significant for all three bandwidths. For example, using the 300 bandwidth, the coefficient on SPT is -5.975 with $t$-stat of -2.23 . When institutional ownership is at its mean (0), managers are less likely to issue forecasts when speculation is greater. One standard deviation increase in $S P T$ is associated with $57.33 \%$ lower likelihood of managers issuing a forecast, on average. We also find that $S P T \times I N S T$ is positive and significant for each bandwidth. Using the 300 bandwidth, the coefficient on SPT $\times I N S T$ is 2.058 with $t$-stat of 3.31 . This finding shows that as short-sale constraints become more binding (i.e., when institutional ownership decreases), managers are even less likely to issue a forecast in response to greater speculative trading. For example, when institutional ownership is at the fifth percentile, one standard deviation increase in $S P T$ is associated with $60.82 \%$ lower likelihood of managers issuing a forecast, on average.

\section{[Insert Table 4 Here]}

In Table 5 we examine the relationship between speculation and the precision of management earnings forecasts (Precision). We use the specificity of management forecasts to proxy for information precision: 3 for a point forecast; 2 for a range forecast; 1 for an open-ended interval forecast; 0 for a qualitative forecast; and -1 for no forecast. We use all quarterly and annual earnings forecasts in September and October of each respective year. ${ }^{21}$ Panel A of Table 5 shows

${ }^{21} \mathrm{We}$ only focus on earnings forecasts in this analysis because there are relatively few sales forecasts during our sample period. 
the results using a linear model. We find that $S P T$ is negative and highly statistically significant for all three bandwidths. For example, using the 300 bandwidth, the coefficient on SPT is -3.223 with $t$-stat of -2.35 . When institutional ownership is at its mean (0), managers issue less precise forecasts when speculation is greater. We also find that SPT $\times$ INST is positive and significant for each bandwidth. As short sales become more binding (i.e., when institutional ownership decreases), managers issue even less precise forecasts in response to greater speculative trading. Unfortunately, this analysis cannot reveal the precise economic significance of the results because the distribution of Precision cannot be modeled accurately. Our results are similar in Panel B of Table 5 where we estimate the model using ordinal logit model. ${ }^{22}$

\section{[Insert Table 5 Here]}

\section{Equity incentives}

In this section, we consider the role of management equity incentives for the relationship between speculation and management forecast activity. Because we study speculative trading and management forecasts over a relatively short horizon of two months (i.e., September and October), we analyze management's ability to benefit from the stock price during that short window. In the short-run, managers can benefit from overvaluation by selling shares or exercising vested in-themoney stock options. Based on this intuition we define STComp (i.e., short-term compensation) as the intrinsic value of in-the-money vested options plus the value of shares held by all executives

as listed on Execucomp for the latest fiscal year, divided by the market value of the stock and

\footnotetext{
${ }^{22}$ In each second-stage regression, we test H0:Residual_SPT $=$ Residual_INST $=$ Residual_SPT $* I N S T=0$. The results show that the residuals from first stage are significantly different from 0 in second stage models. Hence, the inclusion of the residuals may control for the endogeneity in the original equation.
} 
options portfolio held by the executives. ${ }^{23}$ Managers with higher STComp should have a stronger incentive to prolong the speculation so that they can personally benefit from the higher stock price.

To identify this effect, we add STComp, SPT× STComp, INST× STComp, and STComp $\times$ $S P T \times I N S T$ to the regression model given by Eq. (10). We predict that the negative marginal effect of speculation on the frequency of management forecast $(F R E Q)$, the likelihood of issuing a forecast $(P R O B)$, and the precision of management forecasts (Precision) should be stronger when the value of managers' unexercised exercisable options is higher. The results are reported in Table 6. Consistent with our prediction, the coefficients on the interaction terms STComp $\times S P T \times I N S T$ are positive across all specifications. The results are statistically significant for Precision (Panel C). For FREQ (Panel A) and $P R O B$ (Panel B), the results are (marginally) significant for bandwidth 250 and bandwidth 300. Overall, the results are consistent with Bolton et al. (2006) who argue that equity incentives play an important role in motivating managers to boost the current stock price.

\section{[Insert Table 6 Here]}

The analysis above assumes that one reason for managers to alter their voluntary disclosures in response to speculation is to take advantage of the resulting speculative premium. In Table 7, we directly examine whether speculation influences managers' trading of their firms' shares. Managers can benefit from prolonging the speculative premium by selling their stocks for capital gains. Hence, we predict that managers would be more likely to sell their shares in response to greater speculation, especially when short-sale constraints are more binding. We define

\footnotetext{
${ }^{23}$ Baker and Hall (2004) discuss how to determine the appropriate denominator when measuring executive incentives. Our results are similar if we deflate our measure by market value of shareholder equity.
} 
InsiderSell as one if the total value of stock sold exceeds the total value of stock bought by managers during the last quarter of the year (September, October, November, and December). ${ }^{24}$

Our results confirm that executives benefit from speculative trading by selling their shares, especially when short-sale constraints are more binding. For all three bandwidths, the coefficient on SPT is significantly positive (for e.g., coefficient of -3.886 with $t$-stat of 1.98 for bandwidth 300). When institutional ownership is at its mean (0), managers are more likely to sell their shares when speculation is greater. One standard deviation increase in $S P T$ is associated with $51.87 \%$ higher likelihood of insider selling. The results are even stronger when short-sale constraints are more binding. The coefficient on $S P T \times I N S T$ is significantly negative (e.g., coefficient of -1.081 with $t$-stat of -1.89 for bandwidth 300 ). For example, when institutional ownership is at the fifth percentile, one standard deviation increase in SPT is associated with $60.97 \%$ higher likelihood of insider selling.

These findings support our assumption that managers are aware of the effect of speculation on equity prices and trade accordingly.

\section{[Insert Table 7 Here]}

\section{Additional Tests}

A. Management forecasts vs. consensus analyst forecasts

One necessary condition for the existence of a speculative premium is the presence of investors who are optimistic about the stock price relative to other investors (e.g., Miller, 1977; Hong and Stein, 2003; Hong, Scheinkman, and Xiong, 2006). When short sales constraints are

\footnotetext{
${ }^{24}$ We use a longer window to increase the number of insider transactions in the test. Our results are similar if we only focus on September and October. We consider the CEO, President, CFO, Chief Operating Officer and Chief Investment Officer as managers and calculate the total value of the stocks purchased or sold by them.
} 
binding, the price reflects the beliefs of the most optimistic investors. Managers in turn have incentives to support or cater to these optimistic beliefs. ${ }^{25}$ Any contradictory news is likely to reduce the speculative premium. As a result, if managers are to issue a forecast, they should be more likely to issue good news forecast when there is greater speculation.

We focus on range and point earnings forecasts issued in September and October of each respective year. For range forecasts, Ciconte et al. (2013) find that managers' earnings expectations are closer to the upper bound of the range rather than to the midpoint. Hence, for range forecasts, we use the upper bound to represent the expectation of managers. We use the consensus (median) analyst earnings forecast within 90 days before the corresponding guidance day to proxy for the market's expectations prior to the issuance of management forecasts. We infer that a management forecast is good news if it is greater than or equal to the consensus analyst earnings forecast. In this case, GoodNews is set to one. Otherwise, GoodNews is set to zero.

There is a potential for a self-selection bias because the sample contains only firms that provide range and point earnings forecasts. We use the Heckman (1979) self-selection model to mitigate this issue. We estimate a standard Probit selection model including all exogenous variables from Eq. (10) as well as additional firm-specific characteristics that help explain the choice to issue a range or point forecast. ${ }^{26}$ The model is shown below:

$$
\begin{aligned}
& p(\text { range or point } \mid X)_{i .(t, t+1)}= \\
& \quad \varphi\left(a_{1}+\gamma_{1} R_{2000_{i, t}}+\gamma_{2} \text { inst }_{i, t-1}+\gamma_{3} M B_{t-1}+\gamma_{4} \text { Coverage }_{t-1}+\gamma_{5} \text { UC }_{t-1}+\right. \\
& \gamma_{6} \text { Freq }_{t-1}+\gamma_{7} \text { LnMV }_{t-1}+\gamma_{8} \text { PIN }_{t-1}+\gamma_{9} \text { Liquid }_{t-1}+\gamma_{10} \text { Lnasset }_{i, t-1}+\gamma_{11} R D_{t}+ \\
& \gamma_{12} \text { Float }_{t}+\gamma_{13} \text { Rank }_{t}+\gamma_{14} \text { Finance }_{t}+\gamma_{15} \text { ROA }_{t}+\gamma_{16} \text { Loss }_{t}+\gamma_{17} \text { lev }_{t}+
\end{aligned}
$$

\footnotetext{
${ }^{25}$ The implication is similar to the catering theory of overinvestment (Polk and Sapienza, 2009).

${ }^{26}$ See Ajinkaya et al (2005); Feng et al (2009); Li and Zhang (2014).
} 


$$
\begin{aligned}
& \gamma_{18} \text { Litigation }_{t}+\gamma_{19} \text { Stdoc }_{t}+\gamma_{20} \text { Ret }_{t}+\gamma_{21} \text { Invest }_{t}+\gamma_{22} \text { dividend }_{t}+ \\
& \left.\gamma_{23} \text { Growt }_{t}+\sum \text { year }+e_{i, 5}\right)
\end{aligned}
$$

We add the inverse Mills ratio from Eq. (11) as an additional control variable in Eq. (10). ${ }^{27}$ The results are reported in Table 8. For each bandwidth, the coefficient on SPT is significantly positive and the coefficient on $S P T \times I N S T$ is significantly negative. For example, using the 300 bandwidth, the coefficient on SPT is 4.923 with a $t$-stat of 2.15 , while the coefficient on SPT $\times I N S T$ is -2.742 with a $t$-stat of -2.24 . In terms of average marginal effects, one standard deviation increase in SPT is associated with $37.13 \%$ increase in the likelihood of managers issuing good news forecasts when institutional ownership is at its mean 0 . When institutional ownership is at its fifth percentile, one standard deviation increase in SPT is associated with $49.32 \%$ increase in the likelihood of managers issuing good news on average. This result shows that managers are more likely to support or cater to the beliefs of optimistic investors in response to speculation, especially when short-sale constraints are more binding.

\section{[Insert Table 8 Here]}

\section{B. Excess returns around management forecast dates}

Our analysis of the likelihood, frequency, and precision of management forecasts assumes that management forecasts reduce the speculative premium. In this section, we provide evidence on this assumption by examining the excess returns around management forecast dates. We use the cumulative three-day excess return around the management forecast date as the dependent variable in Eq. (10). Table 9 reports the results. We find that on average SPT is not reliably associated with excess stock returns around management forecast dates. However, as short-sale

\footnotetext{
${ }^{27}$ Heckman sample selection and Instrumental variable or Simultaneous Equations Model: https://www.statalist.org/forums/forum/general-stata-discussion/general/1295287-heckman-sample-selection-andinstrumental-variable-iv-or-simultaneous-equations-model
} 
constraints become more binding, the negative association between excess returns and speculative trading becomes stronger $(S P T \times I N S T$ is positive and marginally significant for all three bandwidths). These findings provide some support for our assumption that management forecasts reduce the speculative premium in our setting. These findings are also consistent with previous research showing that earning announcements and management forecasts reduce overvaluation (Berkman et al., 2009; Seybert and Yang, 2012).

\section{[Insert Table 9 Here]}

\section{Regulation $\mathrm{SHO}$}

Although institutional ownership is a commonly used proxy for short-sale constraints, institutional ownership also proxies for external monitoring and investor sophistication. In this section, we analyze whether our results are robust to using an alternative proxy for short-sale constraints. We take advantage of Regulation SHO that relaxes short-sale constraints for randomly chosen Russell firms to re-examine the primary results.

In July 2004, the SEC approved Rule 202T, which established a pilot program to study the effect of short-sale constraints on the price formation process. The program selected a random sample for 968 Russell 3000 firms for which the short sale uptick rule was suspended from 2005 to 2007. Grullon et al. (2015) report that firms in the pilot program experienced in an increase in short selling. We construct a dummy variable $S H O$ that equals one if a firm in the Russell 3000 sample belongs to the pilot program, and zero otherwise. For this test, our analysis is restricted to the period from 2004 to 2006. We then estimate Eq. (12) for each dependent variable using SHO instead of INST as a proxy for short-sale constraints.

$$
\begin{array}{r}
\text { FORECAST }_{i, t+1}=b+\theta_{0} S H O+\theta_{1} S P T_{i, t}+\theta_{2} S H O * S P T_{i, t}+\theta_{3} I_{N S T_{i, t}}+\theta_{4} \text { Rank }_{i, t}+ \\
\theta_{5} \text { LnMV }_{i, t}+\theta_{6} \text { Float }_{i, t}+\theta_{7} \text { Ret }_{i, t}+\theta_{8} \hat{\epsilon}_{1, i}+\theta_{9} \hat{\epsilon}_{2, i}+\sum \text { year }+v_{i, t}
\end{array}
$$


The results are reported in Table 10. Consistent with our prior findings, we find that the coefficients on SPT are negative and coefficients on $S P T^{*} S H O$ are positive across all specifications. The coefficients on $S P T * S H O$ are statistically significant at conventional level except for Precision using the 200 and 250 bandwidth. The lower statistical significance might reflect the smaller sample size (i.e., we have only three years of data). Despite this limitation, the results using Regulation SHO are consistent with our main results.

\section{[Insert Table 10 here]}

\section{Contemporaneous analyst coverage}

This section explores the possibility that the relationship between speculation and the characteristics of management forecast is confounded by the effect of contemporaneous analyst coverage. Lee and So (2017) show that analysts are more likely to cover underpriced firms because these firms are more likely to generate higher returns for their clients. Hence, it is possible that some analysts choose not to cover a firm when its speculative premium is greater. In turn, managers may alter their disclosures in response to analyst coverage (e.g., Anantharaman and Zhang, 2011). To alleviate this concern, we control for contemporaneous analyst coverage in Eq. (10) instrumented using expected coverage based on broker size (see $\mathrm{Yu}$ (2008)). The results are reported in Table 11. We find that controlling for analyst coverage does not affect our results.

\section{[Insert Table 11 here]}

\section{E. Alternative Russell ranks}

In this section, we follow the identification strategy of Crane et al. (2015) to construct the bandwidths around the Russell 1000/2000 threshold and test our hypotheses. We rank all Russell 3000 firms based on market capitalization at the end of May rather than based on index weights, 
and control for the distance to the threshold (Rank-1000) and the interaction R2000*(Rank-1000). The model is specified as follows and is estimated by OLS:

$$
\begin{aligned}
& S P T_{i, t}=a_{1}+\beta_{1} R 2000_{i, t}+\beta_{2}\left(\operatorname{Rank}_{i, t}-1000\right)+\beta_{3} R 2000_{i, t} \times\left(\operatorname{Rank}_{i, t}-1000\right)+ \\
& \beta_{4} \text { Float }_{i, t}+\sum \text { year }+\epsilon_{i, 1} \\
& I N S T_{i, t}=a_{2}+\varphi_{1} \text { IVinst }_{i}+\varphi_{2}\left(\operatorname{Rank}_{i, t}-1000\right)+\varphi_{3} R 2000_{i, t} \times\left(\operatorname{Rank}_{i, t}-1000\right)+ \\
& \varphi_{4} \text { Float }_{i, t}+\sum \text { year }+\epsilon_{i, 2} \\
& I N S T \times S P T_{i, t}=a_{3}+\delta_{1} R 2000_{i, t} \times \text { IVinst }_{i}+\delta_{2}\left(\text { Rank }_{i, t}-1000\right)+\delta_{3} R 2000_{i, t} \times \\
& \left(\text { Rank }_{i, t}-1000\right)+\delta_{4} \text { Float }_{i, t}+\sum \text { year }+\epsilon_{i, 3} \\
& \text { Forecast }_{i, t+1}=a_{4}+\psi_{1} S P T_{i, t}+\psi_{3} I N S T_{i, t}+\psi_{3} I N S T * S P T_{i, t}+\psi_{4}\left(\text { Rank }_{i, t}-1000\right)+ \\
& \psi_{5} R 2000_{i, t} \times\left(\text { Rank }_{i, t}-1000\right)+\psi_{6} \text { Float }_{t i, t}+\psi_{7} \widehat{\epsilon_{1, l}}+\psi_{8} \widehat{\epsilon_{2, l}}+\psi_{9} \widehat{\epsilon_{3, l}}+ \\
& \sum y e a r+e_{i}
\end{aligned}
$$

Table 12 reports the two-stage results using three bandwidths. Consistent with our prior results, the coefficients on SPT are all negative and statistically significant and the coefficients on $I N S T * S P T$ are all positive and are significant in seven out of nine specifications. Overall, the results show that our prior findings are not driven by the choice of how we compute Russell ranks.

$$
\text { [Insert Table } 12 \text { here] }
$$

\section{Conclusions}

This paper investigates the relationship between speculation and management forecast activity. We use the three-pass regression filter of Kelly and Pruitt (2015) to construct a proxy for speculation. We then use the yearly Russell 1000/2000 reconstitution to establish a causal relationship between speculation and management forecast activity. We find that speculation reduces the frequency, likelihood, and the precision of management forecasts. Consistent with theory, the results are stronger when short-sale constraints are more binding. We link the findings to management's equity incentives by showing that our results are stronger when managers stand 
to gain more from overvalued equity. We also find that managers are more likely to sell shares and issue good news forecasts when speculative trading is greater and short-sale constraints are more binding.

Overall, our evidence suggests that managers are not passive bystanders when investors speculate in the company's shares. Instead, managers act opportunistically to prolong the speculative trading, especially when short-sale constraints are more binding. They keep silent when possible, or issue fewer and more ambiguous forecasts. This may explain why the speculative premium may persist or even increase despite management's voluntary disclosures. 


\section{References}

Ajinkya, B.B., Bhojraj, S., and Sengupta, P., 2005. The association between outside directors, institutional investors and the properties of management earnings forecasts. Journal of Accounting Research 43 (3): 343-376.

Anantharaman, D., and Zhang, Y., 2011. Cover me: Managers' responses to changes in analyst coverage in the post-regulation FD period. Accounting Review 86 (6): 1851-1885.

Anderson, E. W., Ghysels, E., and Juergens, J. L., 2005. Do Heterogeneous Beliefs Matter for Asset Pricing? Review of Financial Studies 18(3):875-924.

Andreou, P.C., Kagkadisz, A., Philipx, D., and Tuneshev, R., 2018. Differences in Options Investors' Expectations and the Cross-Section of Stock Returns. Journal of Banking \& Finance 94: 315-336

Amihud, Y.,2002. Illiquidity and stock returns: cross-section and time-series effects. Journal of Financial Markets 5(1): 31-56,

Appel, I.R., Gormley, T.A, and Keim, D.B., 2016. Passive investors, not passive owners. Journal of Financial Economics 121 (1): 111-141.

Asquith, P., Pathak, P.A., and Ritter, J.R., 2005. Short interest, institutional ownership, and stock returns. Journal of Financial Economics 78 (2): 243-276.

Baginski, S. P., Conrad, E. J, and Hassell, J. M., 1993. The Effects of Management Forecast Precision on Equity Pricing and on the Assessment of Earnings Uncertainty. Accounting Review 68: 913-927.

Baker, G. P., and Hall, B. J., 2004. CEO Incentives and Firm Size. Journal of Labor Economics. 22(4): $767-798$

Bamber, L.S, Barron, O.E, and Stober, T.L., 1999., Differential interpretations and trading volume. Journal of Financial \& Quantitative Analysis 34 (3): 369-386.

Bergman, N.K., and Roychowdhury, S., 2008., Investor sentiment and corporate disclosure. Journal of Accounting Research 46 (5): 972-1057.

Berkman, H., Dimitrov, V., Jain, P. C., Koch, P. D., and Tice, S., 2009. Sell on the news: Differences of opinion, short-sales constraints, and returns around earnings announcements. Journal of Financial Economics 92 (3): 376-399.

Bessembinder, H., and Chan, K., 1996. An empirical examination of information, differences of opinion, and trading activity. Journal of Financial Economics, 40(1):105-134.

Beyer, A., Cohen, D. A., Lys, T. Z., and Walther, B. R., 2010., The financial reporting environment: Review of the recent literature. Journal of Accounting and Economics 50 (2): 296-343.

Biais, B., and Bossaerts, P., 1998. Asset prices and trading volume in a beauty contest. Review of Economic Studies 65 (2): 307-340. 
Bird, A., and Karolyi, S. A., 2017. Governance and taxes: Evidence from regression discontinuity. Accounting Review 92 (1): 29-50.

- 2016. Do institutional investors demand public disclosure? Review of Financial Studies 29 (12): 3245-3277.

Boehme, R.D., Danielsen, B.R., and Sorescu, S.M., 2006. Short-sale constraints, differences of opinion, and overvaluation. Journal of Financial and Quantitative Analysis 41 (2): 455-487.

Bolton, P., Scheinkman, J, and Xiong, W., 2006. Executive compensation and short-termist behaviour in speculative markets. Review of Economic Studies 73 (3): 577-610.

Boone, A.L., and White, J.T., 2015. The effect of institutional ownership on firm transparency and information production. Journal of Financial Economics 117 (3): 508-533.

Bris, A., Goetzmann, W. N., and Zhu, N., 2007. Efficiency and the Bear: Short Sales and Markets Around the World. Journal of Finance 62(3): 029-1079.

Buraschi, A., and Jiltsov, A., 2006. Model uncertainty and option markets with heterogeneous beliefs. Journal of Finance 61 (6): 2841-2897.

Carlin, B.I., Longstaff, F. A., and Matoba, kyle., 2014. Disagreement and asset prices. Journal of Financial Economics 114 (2) (11): 226-238.

Chang, E. C., Cheng, J. W., and Yu, Y.,2007. Short-Sales Constraints and Price Discovery: Evidence from the Hong Kong Market. Journal of Finance 62(5):2097-2121

Chang, Y., Hong, H., and Liskovich, I., 2015. Regression discontinuity and the price effects of stock market indexing. Review of Financial Studies 28 (1): 212-246.

Chen, J., Hong, H., and Stein, J. C., 2002. Breadth of ownership and stock returns. Journal of Financial Economics, 66(2/3): 171-205.

Chen, S, Huang, Y., Li, N and Sheclin, T. J., 2018. How Does Quasi-Indexer Ownership Affect Corporate Tax-Planning. Journal of Accounting and Economics, Forthcoming.

Chen, C.R., Lung P. P., and Wang, F. A., 2009. Stock market mispricing: Money illusion or resale option? Journal of Financial \& Quantitative Analysis 44 (5): 1125-1147.

Cheng, Q., Luo, T., and Yue, H., 2013. Managerial incentives and management forecast precision. Accounting Review 88 (5): 1575-1602.

Chi, J., and Gupta, M., 2009. Overvaluation and earning management. Journal of Banking \& Finance, 33(9):1652-1663.

Ciconte, W., Kirk, M., and Tucker, J., 2014. Does the midpoint of range earnings forecasts represent managers' expectations? Review of Accounting Studies 19 (2): 628-660.

Coles, J.L., Daniel, N.D., and Naveen, L., 2006. Managerial Incentives and Risk-Taking. Journal of Financial Economics 79, 431-468. 
Crane, A.D., Michenaud, S., and Weston, J. P., 2016. The effect of institutional ownership on payout policy: Evidence from index thresholds. Review of Financial Studies 29 (6): 1377-1408.

David, A., 2008. Heterogeneous beliefs, speculation, and the equity premium. Journal of Finance 63 (1): 41-83.

De Long, J. B., Shleifer, A., Summers, L. H., and Waldmann, R. J., 1990. Noise trader risk in financial markets. Journal of Political Economy 98(4): 703-738.

Diether, K.B., Malloy, C. J., and Scherbina, A., 2002. Differences of opinion and the cross section of stock returns. Journal of Finance 57 (5): 2113-2141.

Dorobantu, F., 2005. Information disclosure in speculative market. Duke University, Working paper.

Doukas, J. A., Kim, C. (Francis), \& Pantzalis, C., 2006. Divergence of Opinion and Equity Returns. Journal of Financial and Quantitative Analysis 41(3): 573-606.

Duffie, D., Gârleanu, N., and Pedersen, L. H., 2007. Valuation in Over-the-Counter Markets. Review of Financial Studies 20(6): 1865-1900.

Dye, R., 1985. Disclosure of Nonproprietary Information. Journal of Accounting Research 23(1): 123-145.

Easley, D., Kiefer, N., O'Hara, M., and Paperman, J., 1996. Liquidity, Information, and Infrequently Traded Stocks. Journal of Finance, 51(4): 1405-1436

Fellner, G., and Theissen, E., 2014. Short sale constraints, divergence of opinion and asset prices: Evidence from the laboratory. Journal of Economic Behavior and Organization 101 (5): 113-127.

Feng, M., Li, C., and McVay, S., 2009 Internal control and management guidance. Journal of Accounting and Economics 48(2/3):190-209.

Friesen, G.C., Zhang, Y., and Zorn T. S., 2012. Heterogeneous beliefs and risk-neutral skewness. Journal of Financial and Quantitative Analysis 47 (4): 851-872.

Garfinkel, J, A., 2009. Measuring investors' opinion divergence. Journal of Accounting Research 47 (5): $1317-48$.

Garfinkel, J, A., and Sokobin, J., 2006. Volume, opinion divergence, and returns: A study of post--earnings announcement drift. Journal of Accounting Research 44 (1): 85-112.

Geczy, C. C., Musto, D. K., and Reed, A. V., 2002. Stocks are special too: an analysis of the equity lending market. Journal of Financial Economics, 66(2/3): 241-269.

Gilchrist, S., Himmelberg, C. P., and Huberman, G., 2005. Do stock price bubbles influence corporate investment? Journal of Monetary Economics 52 (4): 805-827.

Graham, J. R., Harvey, C. R., and Rajgopal, S., 2005. The economic implications of corporate financial reporting. Journal of Accounting \& Economics 40(1-3): 3-73.

Grullon, G., Michenaud, S., and Weston, J. P., 2015. The real effects of short-selling constraints. Review of Financial Studies 28 (6): 1737-1767. 
Harris, M., and Raviv. A., 1993. Differences of opinion make a horse race. Review of Financial Studies 6 (3) (09): 473-506.

Harrison, J. M., and Kreps, D. M., 1978. Speculative investor behavior in a stock market with heterogeneous expectations. Quarterly Journal of Economics 92 (2): 323-336.

Healy, P.M., and Palepu, K. G., 2001. Information asymmetry, corporate disclosure, and the capital markets: A review of the empirical disclosure literature. Journal of Accounting and Economics 31 (13): 405-440.

Heckman, J., 1979. Sample Selection Bias as a Specification Error. Econometrica 47 (1): 153-161.

Hertzberg, A., 2018. A theory of disclosure in speculative market. Management Science 64(12): 57875806

Hong, H., Scheinkman, J., and Xiong, W., 2006. Asset float and speculative bubbles. Journal of Finance 61 (3): 1073-1117.

Hong, H., and Stein, J. C., 2003. Differences of Opinion, Short-Sales Constraints, and Market Crashes. Review of Financial Studies, 16(2): 487-525.

Hong, H., and Stein, J. C.,2007. Disagreement and the stock market. Journal of Economic Perspectives 21 (2): 109-128.

Huang, R., Krishnan, M., Shon, J., and Zhou, P., 2017. Who Herds? Who Doesn't? Estimates of Analysts' Herding Propensity in Forecasting Earnings. Contemporary Accounting Research 34 (1): 374-399.

Jensen, M, C., 2005. Agency costs of overvalued equity. Financial Management 34 (1): 5-19.

Kaldor, N., 1939. Speculation and Economic Stability. Review of Economic Studies 7(1): 1-27.

Kandel, E., and Pearson, N. D., 1995. Differential interpretation of public signals and trade in speculative markets. Journal of Political Economy 103 (4): 831-872.

Kelly, B., and Pruitt, S., 2015. The three-pass regression filter: A new approach to forecasting using many predictors. Journal of Econometrics 186 (2): 294-316.

Khan, N., Srinivasan, S., and Tan, L., 2017. Institutional ownership and corporate tax avoidance: New evidence. Accounting Review 92 (2): 101-122.

Kyle, A. S., and Wang, F. A., 1997. Speculation Duopoly With Agreement to Disagree: Can Overconfidence Survive the Market Test? Journal of Finance 52(5):2073-2090

Lamont, O. A., and Thaler, R. H., 2003. Can the Market Add and Subtract? Mispricing in Tech Stock Carveouts. Journal of Political Economy 111(2): 227-268

Lee, C., and So, E.C., 2017., Uncovering expected returns: Information in analyst coverage proxies. Journal of Financial Economics 124 (2): 331-348.

Lev, B., and Penman, S. H., 1990. Voluntary Forecast Disclosure, Nondisclosure, and Stock Prices. Journal of Accounting Research 28(1): 49-76. 
Li, Y., and Zhang, L., 2015., Short selling pressure, stock price behavior, and management forecast precision: Evidence from a natural experiment. Journal of Accounting Research 53 (1): 79-117.

Light, N., Maslov, D., and Rytchkov, O., 2017. Aggregation of information about the cross section of stock returns: A latent variable approach. Review of Financial Studies 30 (4): 1339-1381.

Marra, G., and Radice, R., 2011. A flexible instrumental variable approach. Statistical Modeling: An International Journal 11 (6): 581-603.

Mei, J., Scheinkman, J., and Xiong, W., 2009. Speculative Trading and Stock Prices: Evidence from Chinese A-B Share Premia. Annals of Economics and Finance 10 (2): 225-255.

Milgrom, P., and Stokey, N.,1982. Information, Trade, and Common Knowledge. Journal of Economic Theory 26(1):17-27.

Morris, S., 1995. The common prior assumption in economic theory. Economics and Philosophy 11 (2): 227-253.

-1996. Speculative investor behavior and learning. Quarterly Journal of Economics 111 (4): 11111133.

Miller, E. M., 1977. Risk, uncertainty, and divergence of opinion. Journal of Finance (4): 1151-1168.

Morgan, S., and Winship, C., 2007. Counterfactuals and Causal Inference: Methods and Principles for Social Research, Cambridge University Press.

Nagel, S., 2005. Short sales, institutional investors and the cross-section of stock returns, Journal of Financial Economics 78(2):277-309,

Odean, T. 1998. Are Investors Reluctant to Realize Their Losses? Journal of Finance 53(5): 1775-1798.

Ofek, E., and Richardson, M. (2003). DotCom Mania: The Rise and Fall of Internet Stock Prices. Journal of Finance 58(3), 1113-1137.

Palfrey, T, R., and Wang, S. W., 2012. Speculative overpricing in asset markets with information flows. Econometrica 80 (5): 1937-1976.

Pan, L, Tang, Y., and Xu, J., 2016. Speculation and stock returns. Review of Finance 20 (5): 1835-65.

Penman, S. H., 1982. Insider Trading and the Dissemination of Firms' Forecast Information. Journal of Business, 55(4): 479-503

Penman, S. H., 1983. The Predictive Content of Earnings Forecasts and Dividends. Journal of Finance, 38(4): 1181-1199.

Polk, C., Sapienza, P., 2009. The Stock Market and Corporate Investment: A Test of Catering Theory. Review of Financial Studies 22 (1): 187-217

Prado, M. P., Saffi, P. A. C., and Sturgess, J., 2016. Ownership structure, limits to arbitrage, and stock returns: Evidence from equity lending markets. Review of Financial Studies 29 (12): 3211-3244. 
Scheinkman, J., and Xiong. W., 2003. Overconfidence and speculative bubbles. Journal of Political Economy 111 (6): 1183-1219.

Scheinkman, J., and Xiong. W.,2003. Heterogeneous beliefs speculation and trading in financial markets. Paris-Princeton Lectures on Mathematical Finance: 217-250.

Seybert, N., and Yang, H. I., 2012. The party's over: The role of earnings guidance in resolving sentimentdriven overvaluation. Management Science 58 (2): 308-19.

Shleifer, A., and Vishny, R. W., 1997. The Limits of Arbitrage. Journal of Finance. 52(1): 35-55.

Skinner, D. J., 1994. Why Firms Voluntarily Disclose Bad News. Journal of Accounting Research 32:3860

Tirole, J., 1982. On the possibility of speculation under rational expectations. Econometrica 50 (5): 11631181.

Varian, H., 1985. Divergence of opinion in complete markets: A note. Journal of Finance 40 (1): 309-317.

Verrecchia, R, E., 2001. Essays on disclosure. Journal of Accounting \& Economics 32 (1-3): 97-180.

—. 1983. Discretionary disclosure. Journal of Accounting \& Economics 5 (3): 179-194.

Warusawitharana, M., and Whited, T. M., 2016. Equity Market Misvaluation, Financing, and Investment. Review of Financial Studies, 29(3): 603-654.

Wooldridge, J, M. 2002. Econometric Analysis of Cross Section and Panel Data. MIT Press Books, The MIT Press.

Wooldridge, J, M. 2015.Control Function Methods in Applied Econometrics. Journal of Human Resources 50(2):420-445.

Xiong, W., 2013. Bubbles, Crises, and Heterogeneous Beliefs. In J. Fouque \& J. Langsam (Eds.), Handbook on Systemic Risk (pp. 663-713). Cambridge: Cambridge University Press.

Xiong, W., and Yu, J., 2011. The Chinese warrants bubble. American Economic Review 101 (6) (10): 27232753 .

Yu, F., 2008. Analyst coverage and earnings management. Journal of Financial Economics 88(2): 245271.

Zhu, C., 2015. Disagreement in Option Market and Cross Section Stock Returns. Hong Kong University of Science and Technology, Working paper. 


\section{Appendix A : Definition of Variables}

\begin{tabular}{|c|c|}
\hline \multicolumn{2}{|r|}{ Dependent variables } \\
\hline CAR(-1,1) & $\begin{array}{l}\text { The cumulative three-day excess return around management forecast dates. Daily excess return is } \\
\text { calculated relative to the CRSP value-weighted index return (CRSP). }\end{array}$ \\
\hline FREQ & $\begin{array}{l}\text { The number of management forecasts (number of earnings forecasts plus number of sales forecasts) } \\
\text { during September and October of each respective year (IBES) }\end{array}$ \\
\hline$P R O B$ & $\begin{array}{l}1 \text { if a firm issues at least one management forecast during September and October, and } 0 \text { otherwise } \\
\text { (IBES). }\end{array}$ \\
\hline Precision & $\begin{array}{l}3 \text { for a point forecast during September and October, } 2 \text { for an interval forecast, } 1 \text { for an open-ended } \\
\text { forecast, } 0 \text { for a qualitative forecast, and }-1 \text { for no forecast. (IBES) }\end{array}$ \\
\hline GoodNews & $\begin{array}{l}1 \text { if a manager issues an EPS forecast during September and October greater than or equal to the median } \\
\text { analyst EPS forecast, } 0 \text { otherwise (IBES). }\end{array}$ \\
\hline InsidersSell & $\begin{array}{l}1 \text { if the total value of stock sold by managers exceeds that of stock bought by managers during the four- } \\
\text { month window (September, October, November and December) of each respective year, and } 0 \text { otherwise } \\
\text { (Thomson Reuters). }\end{array}$ \\
\hline Coverage & The number of analysts covering a firm during September and October of each respective year (IBES). \\
\hline \multicolumn{2}{|r|}{ Main independent variables } \\
\hline$S P T$ & Turnover due to belief heterogeneity, constructed using the three pass regression filter method. \\
\hline$R 2000$ & $\begin{array}{l}1 \text { if a firm is assigned to Russell } 2000 \text { index, and } 0 \text { if a firm is assigned to Russell } 1000 \text { index. The } \\
\text { Russell membership list is provided by FTSE Russell. }\end{array}$ \\
\hline INST & $\begin{array}{l}\text { The percentage of shares held by institutional investors in September of each respective year (Thomson } \\
13 \mathrm{~F} \text { ). }\end{array}$ \\
\hline IVInst -5 & $\begin{array}{l}\text { The average institutional ownership of other firms across different periods. We first calculate the five- } \\
\text { quarter lagged institutional ownership for each firm in each year and then pool these lagged institutional } \\
\text { ownership levels to construct a new sample. For each firm around the Russell } 1000 / 2000 \text { threshold, we } \\
\text { bootstrap } \mathrm{N} \text { observations (i.e., we use } \mathrm{N}=500 \text { ) from this sample with replacement but exclude the values } \\
\text { of the firm itself. The mean of these } \mathrm{N} \text { observations is the instrument for institutional ownership. }\end{array}$ \\
\hline
\end{tabular}

STCOMP Intrinsic value of in-the-money vested options plus the value of shares held by the top 5 executives for the latest fiscal year (Execucomp), divided by the sum of market value of the stock and options portfolio held by these executives. Data on market value of executives' stock and option portfolio is provided by Lalitha Naveen at https://sites.temple.edu/lnaveen/data/; see Coles, Daniel, and Naveen (2006)).

$\mathrm{SHO} \quad 1$ if a firm is chosen to participate in the SEC SHO pilot program, and 0 otherwise.

\section{Other control variables}

\begin{tabular}{|c|c|}
\hline \multicolumn{2}{|r|}{ Other control variables } \\
\hline Rank & Rank order of Russell firms based on index weights. \\
\hline Float & $\begin{array}{l}\text { The difference between the rank based on market values at the end of May and the rank based on index } \\
\text { weights (Crane et al., 2015). }\end{array}$ \\
\hline Ret & Average daily stock return for September of each respective year (CRSP). \\
\hline$L n m v$ & The logarithm of a firm's market capitalization at the end of May of each respective year (CRSP). \\
\hline Residual_SPT & $\begin{array}{l}\text { The residual from the following equation, which captures the endogenous component of SPT, } \\
\text { SPT }_{\mathrm{i}, \mathrm{t}}=\mathrm{a}_{1}+\alpha_{2} \mathrm{R}_{2000_{\mathrm{i}, \mathrm{t}}}+\alpha_{3} \operatorname{Rank}_{\mathrm{i}, \mathrm{t}}+\alpha_{4} \mathrm{MV}_{\mathrm{i}, \mathrm{t}}+\alpha_{5} \text { Float }_{\mathrm{i}, \mathrm{t}}+\alpha_{6} \operatorname{Ret}_{\mathrm{i}, \mathrm{t}}+\sum \text { year }+\epsilon_{\mathrm{i}, 1}\end{array}$ \\
\hline Residual_INST & $\begin{array}{l}\text { The residual from the following equation, which captures the endogenous component of INST, } \\
\text { INST }_{i, t}=\beta_{1}+\beta_{2} \text { IVinst }_{i}+\beta_{3} \text { Rank }_{i, t}+\beta_{4} \text { MV }_{i, t}+\beta_{5} \text { Float }_{i, t}+\beta_{6} \text { Ret }_{i, t}+\sum \text { year }+\epsilon_{i, 2}\end{array}$ \\
\hline Residual_SPT $\times I N S T$ & $\begin{array}{l}\text { The residual from the following equation, which possibly captures the endogenous component of } \\
\text { interaction term } S P T^{*} I N S T \text {, } \\
\text { SPT } \times \text { INST }_{\mathrm{i}, \mathrm{t}}=\gamma_{1}+\gamma_{2} \mathrm{R} 000_{\mathrm{i}, \mathrm{t}} \times \mathrm{IVinst}_{\mathrm{i}}+\gamma_{3} \text { Rank }_{\mathrm{i}, \mathrm{t}}+\gamma_{4} \mathrm{MV}_{\mathrm{i}, \mathrm{t}}+\gamma_{5} \text { Float }_{\mathrm{i}, \mathrm{t}}+\gamma_{6} \operatorname{Ret}_{\mathrm{i}, \mathrm{t}}+\sum \text { year }+\epsilon_{\mathrm{i}, 3}\end{array}$ \\
\hline$M / B$ & $\begin{array}{l}\text { Market-to-book ratio. We use market capitalization as of September and latest available book value of } \\
\text { equity prior to September (Compustat). }\end{array}$ \\
\hline Loss & $\begin{array}{l}1 \text { if the latest available quarterly net income at September or August is negative, and } 0 \text { otherwise } \\
\text { (Compustat). }\end{array}$ \\
\hline$U C$ & $\begin{array}{l}\text { Proxy for uncertainty, defined as return volatility no driven by speculative trading. It is calculated as the } \\
\text { residual from a cross-sectional regression of volatility of excess returns }(V O L) \text { on SPT in August of each } \\
\text { respective year. }\end{array}$ \\
\hline Liquidity & Proxy for liquidity using data for August. See Amihud (2002). \\
\hline & Liquidity $=-\log \left(\frac{1}{\text { Day }} \sum \frac{\mid \text { Ret }_{i, t} \mid}{\text { Trading Volume }_{i, t}}\right) .(\mathrm{CRSP})$ \\
\hline Finance & $\begin{array}{l}\text { Net financing cash flow scaled by total assets for the latest fiscal quarter ending in or prior to September } \\
\text { (Compustat). }\end{array}$ \\
\hline
\end{tabular}


Invest Capital expenditure scaled by total assets for the latest fiscal quarter ending in or prior to September (Compustat).

$R \& D \quad$ Research and development expenditures divided by total assets for the latest fiscal quarter ending in or prior to September; set to 0 if it is missing (Compustat).

Lev

Total debt scaled by total asset for the latest fiscal quarter ending in or prior to September (Compustat).

PIN Probability of informed trading for the latest fiscal quarter ending in or prior to September. See Easley et al. (1996). Data are provided by Stephen Brown at http://scholar.rhsmith.umd.edu/sbrown/pin-data.

Litigation $\quad 1$ if the firm operates in a high-litigation industry (SIC codes 2833-2836; 3570-3577; 3600-3674; 52002961; and 7370-7374), and 0 otherwise (Compustat).

Lnasset Logarithm of total asset for the latest fiscal quarter ending in or prior to September (Compustat).

ROA

Divdend

Growth

Net income scaled by total asset for the latest fiscal quarter ending in or prior to September (Compustat).

Dividend per share for the latest fiscal quarter ending in or prior to September (Compustat).

quarter) - 1 (Compustat).

Stdocf The standard deviation of operating cash flow scaled by total asset over the past six quarters. (Compustat).

BIG4 Indicator variable taking 1 if the firm has a BIG 4 auditor, and 0 otherwise.

Ecoverage

Expected coverage of a firm in September and October of each respective year:

Ecoverage $_{i t}=\sum_{j=1}^{n}$ ECoverage $_{i j t}$, where

Ecoverage $_{i j t}=\frac{\text { Brokersize }_{j t}}{\text { Brokersize }_{j t-1}} *$ coverage $_{j t-1}$

Brokersize $_{\mathrm{jt}}$ is the total number of analysts employed by broker $\mathrm{j}$ in September and October;

Brokersize $\mathrm{jt}-1$ is the total number of analysts employed by broker $\mathrm{j}$ in June, July and August.

Coverage $e_{\mathrm{ijt}}$ is the total number of analysts to firm $\mathrm{i}$ by brokerage firm $\mathrm{j}$ in June, July and August. See $\mathrm{Yu}$ (2008).

InverseMills Inverse Mills ratio from the following Probit model:

$p(\text { range or point } \mid X)_{i .(t, t+1)}=\varphi\left(a_{1}+\gamma_{1} R 2000_{i, t}+\gamma_{2}\right.$ inst $_{i, t-1}+\gamma_{3} M B_{t-1}+\gamma_{4}$ coverage $_{t-1}+$ $\gamma_{5} U C_{t-1}+\gamma_{6}$ Freq $_{t-1}+\gamma_{7}$ Lnmv $+\gamma_{8}$ PIN $_{t-1}+\gamma_{9}$ Liquid $_{t-1}+\gamma_{10}$ Lnasset $_{i, t}+\gamma_{11}$ RD $_{t}+$ $\gamma_{12}$ Float $_{t}+\gamma_{13}$ Rank $_{t}+\gamma_{14}$ Finance $_{t}+\gamma_{15}$ ROA $_{t}+\gamma_{16}$ Loss $_{t}+\gamma_{17}$ lev $_{t}+\gamma_{18}$ Litigation $_{t}+$

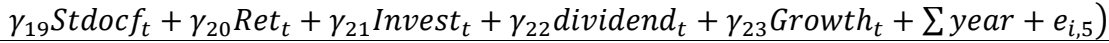

\section{Proxies for heterogeneous beliefs}

TURN Average daily turnover in a month for each stock. At least 16 trading days are required.

$$
\text { Turn }=\frac{1}{N} \sum \frac{\text { Trading Volume }}{i, t},
$$

VOL Volatility of daily excess returns (e.g., Garfinkel, 2009; Berkman et al., 2009). We calculate variance of daily excess return (relative to the return on the value-weighted CRSP index) using all available data for each month. At least 16 trading days are required.

$$
\text { Vol }=\frac{1}{N-1} \sum\left(\text { Exret }_{i, t}-\overline{\text { Exret }_{l, t}}\right)^{2}
$$

Spread Bid-ask spread (Garfinkel, 2009). We calculate the mean of the daily bid-ask spread for each month. At least 16 trading days are required. Spread $=\frac{1}{N}\left[\frac{A s k_{i, t}-B i d_{i, t}}{0.5 *\left(A s k_{i, t}+B i d_{i, t}\right)}\right]$

AUV Unexpected daily trading volume scaled by the standard deviation of residuals from the following regression:

$A U V_{i, t}=\frac{\overline{U V_{l, t}}}{\sigma_{i, t}}$, where $U V_{i, t}=\ln \left(\right.$ Volume $\left._{i, t}\right)-\widehat{f}_{1}\left(\left|R_{i, t}\right|^{+},\left|R_{i, t}\right|^{-}\right)$.

We first regress daily volume on two variables derived from daily stock return for each Russell 3000 firm with a sample from 1996 to 2006. $\left|R_{i, t}\right|^{+}$equals the return's value if the return is positive, and 0 if the return is negative or missing. $\left|R_{i, t}\right|^{-}$equals the return's absolute value if the return is negative, and 0 if the return is positive or missing. Then we calculate the average unexpected volume for each month and the standard deviation of the residuals over the whole estimation period (Garfinkel and Sokobin, 2006; Garfinkel, 2009). The estimation is performed using the local linear regression method.

ADISP Dispersion of analyst forecasts. We calculate the standard deviation of analysts' EPS forecast during each month (e.g., Deither et al., 2002; Garfinkel, 2009). Displ is standard deviation scaled by the average forecast; Disp2 is standard deviation scaled by the average stock price in the corresponding month. We require a minimum of three forecasts for each firm in a given month.

$$
A D i s p 1=\frac{\sqrt{\frac{1}{N-1} \sum\left(A F_{i, t}-\overline{A F_{l, t}}\right)^{2}}}{\left|\overline{A F}_{i, t}\right|} ; A \text { Disp } 2=\frac{\sqrt{\frac{1}{N-1} \sum\left(A F_{i, t}-\overline{A F_{l, t}}\right)^{2}}}{\left|\overline{\text { Prlce }_{l, t}}\right|} \text {, where N }>2
$$


ODISP1 Volume-weighted option strike dispersion. We aggregate daily trading volume of options $\left(\mathrm{V}_{\mathrm{j}}\right)$ for each strike price to obtain monthly trading volume and then calculate the proportion of trading volume attached to each strike price.

$$
\text { ODisp } 1=\frac{\sum_{j=1}^{K} w_{j}\left|S_{j}-\sum_{j=1}^{K} w_{j} S_{j}\right|}{\sum_{j=1}^{K} w_{j} S_{j}}, \text { where } \mathrm{w}_{j}=\frac{V_{j}}{\sum_{j=1}^{K} V_{j}} \text { and } \mathrm{K} \text { is the number of strike price. }
$$

We only consider call and put options satisfying the following two properties: non-ATM options (moneyness between 0.975 and 1.025); and maturities between 7 and 90 days. Additionally, we keep the days in which there are more than four contracts to avoid the effect of thinly-traded options. See Zhu (2015) and Andreou et al. (2018).

ODISP2 Open-interest-weighted option strike dispersions. Given a stock in a certain month, we select the open interest $\left(\mathrm{OI}_{\mathrm{j}}\right)$ of last trading day of this month for each strike price to obtain monthly and then calculate the proportion of open interest attached to each strike price. See Zhu (2015).

$$
\text { ODisp } 2=\frac{\sum_{j=1}^{K} w_{j}\left|S_{j}-\sum_{j=1}^{K} w_{j} S_{j}\right|}{\sum_{j=1}^{K} w_{j} S_{j}}, \text { where } \mathrm{w}_{j}=\frac{O I_{j}}{\sum_{j=1}^{K} O I_{j}} \text { and } \mathrm{K} \text { is the number of strike prices. }
$$

$O I$

Open interest. The average of daily open interest (the sum of call open interest and put open interest) in OTM options of each stock in each month.

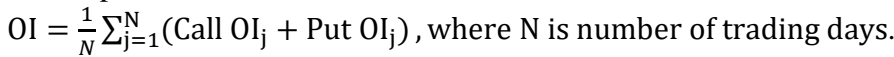

$O V \quad$ Option trading volume. $\mathrm{OV}=\frac{1}{N} \sum_{\mathrm{j}=1}^{\mathrm{N}} \mathrm{OV}_{\mathrm{j}}$, where $O V_{\mathrm{j}}$ is the daily option trading volume for day $\mathrm{j}$ and $\mathrm{N}$ is the number of trading days in a given month. 


\section{Appendix B: Instrument for institutional ownership}

This section discusses how we construct the instrument for institutional ownership. We first calculate the five-quarter lagged institutional ownership for each firm in each year and then pool these lagged institutional ownership data to construct a new sample. ${ }^{28}$ For each firm around the Russell 1000/2000 threshold, we bootstrap N observations (i.e., we use N=500) from this new sample with replacement but exclude the values of the firm itself. The mean of these $\mathrm{N}$ observations is the instrument for institutional ownership.

The exclusion restriction is that the unobservable characteristics of any firm $i$ at time $t$ are uncorrelated with the average institutional ownership of the other $\mathrm{N}$ firms across different periods:

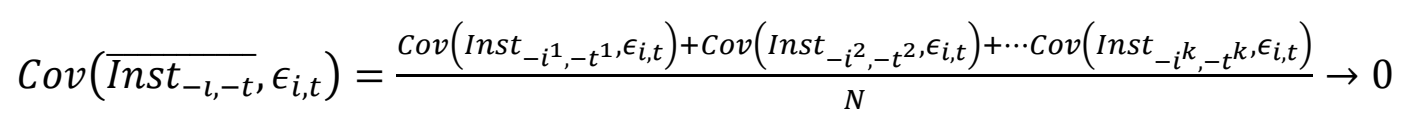

where $-i^{k}$ indicates firm other than $i$ and $-t^{k}$ indicates a time period other than $t$. It is possible that the unobservable characteristics of firm $i$ at time $t$ are correlated with the institutional ownerships of some other firms. However, as long as the sum of the terms in the numerator of Eq. (B1) is small enough compared to $\mathrm{N}$, the exclusion restriction still holds.

The relevance assumption is that the institutional ownership of any firm $i$ at time $t$ is correlated with the average institutional ownership of the other $\mathrm{N}$ firms across different periods:

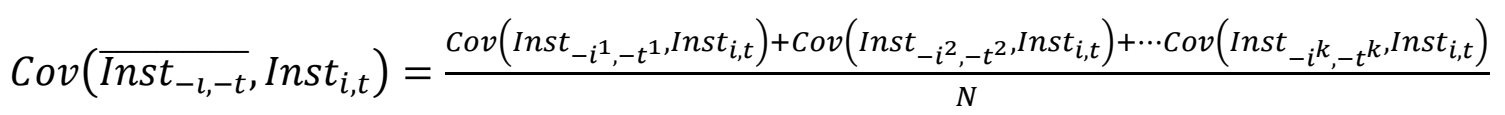

\footnotetext{
${ }^{28}$ We use a five-quarter lag to ensure that institutional ownership is not related to the current Russell index assignment.
} 
As we prove below, $\operatorname{Cov}\left(\overline{\operatorname{Inst}_{-l,-t}}\right.$, Inst $\left._{i, t}\right)$ is non-zero when quarterly institutional ownership of a firm is auto-correlated and different firms are simultaneously affected by the reconstitution of Russell indices.

Proof:

For a firm $i$ or $j$ around the Russell 1000/2000 threshold, we assume that institutional ownership follows AR (1) process:

$$
\begin{aligned}
& \text { Inst }_{i, t}=a+\gamma \text { Inst }_{i, t-1}+\epsilon_{i, t} \\
& \text { Inst }_{j, t}=\delta+\lambda \text { Inst }_{j, t-1}+\epsilon_{j, t}
\end{aligned}
$$

where $t$ is the quarter following reconstitution, $t-1$ is the previous quarter, and $\epsilon_{\mathrm{t}}$ is a random shock (i.e., the reconstitution of Russell indices). ${ }^{29}$ We also assume that $\left(\epsilon_{i, t}\right.$, Inst $\left._{i, t-1}\right)=0$, $\operatorname{Cov}\left(\epsilon_{j, t}\right.$, Inst $\left._{i, t-1}\right)=0, \operatorname{Cov}\left(\epsilon_{j, t}, \epsilon_{i, t-1}\right)=0$, and Inst $t_{i, t}$ and $I n s t_{j, t}$ are stationary (i.e., $|\gamma|<$ 1and $|\lambda|<1) .{ }^{30}$ Then we have:

$$
\begin{gathered}
\operatorname{Cov}\left(\text { Inst }_{j, t}, \text { Inst }_{i, t}\right)=\gamma \lambda \operatorname{Cov}\left(\text { Inst }_{j, t-1}, \text { Inst }_{i, t-1}\right)+\operatorname{Cov}\left(\epsilon_{j, t}, \epsilon_{i, t}\right) \\
\operatorname{Cov}\left(\text { Inst }_{j, t}, \text { Inst }_{i, t}\right)=\operatorname{Cov}\left(\text { Inst }_{j, t-1}, \text { Inst }_{i, t-1}\right)=\frac{\operatorname{Cov}\left(\epsilon_{j, t} \epsilon_{i, t}\right)}{1-\gamma \lambda}
\end{gathered}
$$

As firm $i$ and $j$ are both subject to the reconstitution of the Russell indices, $\operatorname{Cov}\left(\epsilon_{j, t}, \epsilon_{i, t}\right)$ is non-zero and thereby $\operatorname{Cov}\left(\right.$ Inst $_{j, t}$, Inst $\left._{i, t}\right)$ is non-zero.

Similarly, Equation (B7) and (B8) can be derived through recursive substitution.

$$
\begin{aligned}
& \operatorname{Cov}\left(\text { Inst }_{j, t}, \text { Inst }_{i, t-\tau}\right)=\frac{\lambda^{\tau} \operatorname{Cov}\left(\epsilon_{j, t}, \epsilon_{i, t}\right)}{1-\gamma \lambda} \\
& \operatorname{Cov}\left(\text { Inst }_{j, t-\tau}, \text { Inst }_{i, t}\right)=\frac{\gamma^{\tau} \operatorname{Cov}\left(\epsilon_{j, t}, \epsilon_{i, t}\right)}{1-\gamma \lambda}
\end{aligned}
$$

\footnotetext{
${ }^{29}$ We find that the average quarterly institutional ownership of Russell 3000 firms follows AR (1) process during our sample periods.

${ }^{30}$ We make these assumptions for simplicity. Eq. (B2) is likely to hold even if we relax these assumptions.
} 
$\operatorname{Cov}\left(\right.$ Inst $_{j, t}$, Inst $\left._{i, t-\tau}\right)$ and $\operatorname{Cov}\left(\right.$ Inst $_{j, t-\tau}$, Inst $\left._{i, t}\right)$ are non-zero unless $\tau$ goes to infinity. Therefore, the institutional ownership of firm $i$ at $t$ can be correlated with the institutional ownership of firm $j$ at other times. As a result, some of terms in the numerator of Eq. (B2) are nonzero. $\operatorname{Cov}\left(\overline{\operatorname{Inst} t_{-l,-t}}\right.$, Inst $\left._{i, t}\right)$ in Eq. (B2) should also be non-zero as long as these non-zero terms do not fully cancel out. The test results in Section IV.A support this relevance assumption. 
Table 1: Descriptive statistics of the proxies for heterogeneous beliefs

\begin{tabular}{cccccccc}
\hline Variable & Mean & Median & Std dev & Skew & Kurt & Max & Min \\
\hline TURN & 0.007 & 0.005 & 0.006 & 1.416 & 1.174 & 0.024 & 0.0004 \\
VOL & 0.027 & 0.022 & 0.016 & 1.256 & 1.012 & 0.074 & 0.008 \\
SPREAD & 0.011 & 0.007 & 0.011 & 1.476 & 1.706 & 0.048 & 0.0007 \\
ASUV & -0.011 & -0.109 & 0.472 & 0.772 & -0.199 & 1.078 & -0.637 \\
ADISP1 & 0.091 & 0.034 & 0.141 & 2.565 & 6.011 & 0.609 & 0.006 \\
ADISP2 & 0.004 & 0.002 & 0.006 & 2.496 & 5.859 & 0.029 & 0.0003 \\
ODISP1 & 0.092 & 0.083 & 0.047 & 0.782 & 0.064 & 0.206 & 0.022 \\
ODISP2 & 0.101 & 0.089 & 0.068 & 0.757 & -0.034 & 0.262 & 0.002 \\
OI & 70,562 & 6,402 & 146,661 & 2.502 & 5.096 & 559,366 & 43 \\
OV & $6,131.7$ & 906 & 11,864 & 2.433 & 4.815 & 45,307 & 15 \\
\hline
\end{tabular}

This table presents descriptive statistics for the pre-standardized proxies for heterogeneous beliefs. The sample contains Russell 3000 firms, beginning from June 1995 to June 2007. All variables are winsorized at the $1 \%$ level. Variables are defined in Appendix A. 
Table 2: Descriptive statistics of the main variables

Panel A. Russell 1000

\begin{tabular}{ccccccc}
\hline & Mean & Median & Stdev & Skew & Max & Min \\
\hline SPT & 0.35 & 0.29 & 0.60 & 0.14 & 3.00 & -5.73 \\
INST & 0.64 & 0.67 & 0.20 & -0.55 & 0.99 & 0.005 \\
FREQ & 0.51 & 0.00 & 1.01 & 2.78 & 14 & 0.00 \\
PROB & 0.33 & 0.00 & 0.47 & 0.74 & 1.00 & 0.00 \\
Precision & 1.94 & 2.00 & 0.79 & -0.99 & 3.00 & 0.00 \\
Goodnews & 0.19 & 0.00 & 0.39 & 1.57 & 1.00 & 0.00 \\
STDCOMP & 0.66 & 0.69 & 0.25 & -0.31 & 1.26 & 0.07 \\
Insidersell & 0.42 & 0.00 & 0.49 & 0.29 & 1.00 & 0.00 \\
Lnmv & 22.3 & 22.0 & 1.10 & 0.99 & 16.9 & 17.6 \\
Ret & -0.007 & 0.003 & 0.13 & -0.48 & 0.41 & -0.45 \\
\hline
\end{tabular}

Panel B. Russell 2000

\begin{tabular}{ccccccc}
\hline & Mean & Median & Std de & Skew & Max & Min \\
\hline SPT & 0.28 & 0.24 & 0.73 & 0.10 & 4.30 & -4.15 \\
INST & 0.53 & 0.53 & 0.26 & -0.01 & 0.99 & 0.005 \\
FREQ & 0.24 & 0.00 & 0.67 & 3.52 & 7.00 & 0.00 \\
PROB & 0.15 & 0.00 & 0.36 & 1.95 & 1.00 & 0.00 \\
Precision & 1.94 & 2.00 & 0.69 & -1.04 & 3.00 & 0.00 \\
Goodnews & 0.10 & 0.00 & 0.31 & 2.58 & 1.00 & 0.00 \\
Insidersell & 0.33 & 0.00 & 0.47 & 0.71 & 1.00 & 0.00 \\
STDCOMP & 0.66 & 0.70 & 0.28 & -0.34 & 1.27 & 0.07 \\
Lnmv & 19.9 & 19.9 & 0.64 & 0.09 & 16.7 & 22.3 \\
Ret & -0.004 & 0.00 & 0.16 & -0.18 & 0.41 & -0.45 \\
\hline
\end{tabular}

This table presents the descriptive statistics for firms in Russell 1000 and Russell 2000 indices. The full sample includes 32,985 observations from 1996 to 2006. Variables are defined in Appendix A. 
Table 3: The result of the first stage regression

Panel A. Speculation $(S P T)$

\begin{tabular}{cccc}
\hline Variable & Bandwidth: 200 & Bandwidth: 250 & Bandwidth: 300 \\
\hline \multirow{2}{*}{ R2000 } & $0.258^{* * *}$ & $0.213^{* * *}$ & $0.182^{* * *}$ \\
& $(5.03)$ & $(4.67)$ & $(4.63)$ \\
Lnmv & -0.087 & -0.049 & 0.079 \\
& $(-0.61)$ & $(-0.35)$ & $(0.63)$ \\
Rank & $-0.001^{* * *}$ & $-0.001^{* *}$ & -0.0001 \\
& $(-3.33)$ & $(2.18)$ & $(-0.67)$ \\
Float & -0.0002 & -0.0002 & 0.0004 \\
& $(-1.11)$ & $(-0.82)$ & $(0.21)$ \\
Ret & 0.049 & 0.042 & 0.090 \\
Adj R2 & $(0.63)$ & $(0.39)$ & $0.95)$ \\
F-statistic & 0.034 & 0.033 & 0.035 \\
Observations & $10.05^{* * *}$ & $12.24^{* * *}$ & $15.87^{* * *}$ \\
Fixed Effects & 3,092 & 3,862 & 4,617 \\
\hline
\end{tabular}

Panel B. Institutional ownership (INST)

\begin{tabular}{cccc}
\hline Variable & Bandwidth: 200 & Bandwidth: 250 & Bandwidth: 300 \\
\hline \multirow{2}{*}{ IVinst } & $2.678^{* * *}$ & $2.545^{* * *}$ & $2.599^{* * *}$ \\
& $(10.79)$ & $(12.64)$ & $(14.27)$ \\
Lnmv & $-1.400^{* *}$ & $-1.415^{* * *}$ & $-1.349^{* * *}$ \\
& $(-5.82)$ & $(-6.36)$ & $(-6.70)$ \\
Float & -0.001 & $-0.002^{* * *}$ & $-0.001^{* * *}$ \\
& $(-3.42)$ & $(-3.79)$ & $(-3.92)$ \\
Rank & -0.001 & $-0.002^{* * *}$ & $-0.002^{* * *}$ \\
& $(-3.48)$ & $(-4.76)$ & $(-5.71)$ \\
Ret & 0.127 & 0.112 & 0.086 \\
Adj R2 & $(1.17)$ & $(1.17)$ & $(0.98)$ \\
F-statistic & 0.227 & 0.216 & 0.207 \\
Observations & $51.47^{* * *}$ & $58.62^{* * *}$ & $69.78^{* * *}$ \\
Fixed Effects & 4,337 & 5,385 & 6,461 \\
\hline & Year & Year & Year \\
\hline
\end{tabular}

Panel A presents the coefficient estimates from Eq. (6) that examines the effect of index assignment (R2000) on speculation $(S P T)$. The estimates are calculated over $\pm 200, \pm 250$ and \pm 300 ranks from the threshold. Panel B presents the coefficient estimates from Eq. (7) that examines the effect of the average institutional ownership of other firms (IVinst) on standardized institutional ownership (INST). The models are estimated over the 19962006 period using bandwidths of 200, 250 and 300 around the Russell 1000/2000 threshold. Coefficients on $R 2000$ and IVinst are reported with the t-statistics in parentheses. Bootstrapped standard errors are used to calculate $\mathrm{t}$ statistics. Variables are defined in Appendix A. *, **, and $* * *$ indicate significance at the $10 \%, 5 \%$, and $1 \%$ level, respectively. 
Table 4: The joint effect of speculation and short-sale constraints on frequency of management forecasts

Panel A: Frequency of Management Forecasts

\begin{tabular}{cccc}
\hline Variable & Bandwidth: 200 & Bandwidth: 250 & Bandwidth: 300 \\
\hline SPT & $-3.115^{*}$ & $-3.461^{*}$ & $-3.558^{*}$ \\
SPT $\times I N S T$ & $(-1.84)$ & $(-1.90)$ & $(-1.94)$ \\
& $1.309^{* *}$ & $1.385^{* * *}$ & $1.125^{* *}$ \\
INST & $(2.41)$ & $(2.65)$ & $(2.12)$ \\
& -0.252 & -0.006 & -0.033 \\
Lnmv & $(-0.92)$ & $(-0.02)$ & $(-0.14)$ \\
& $-2.356^{*}$ & -1.809 & $-1.827^{*}$ \\
Rank & $(-1.94)$ & $(-1.41)$ & $(-1.83)$ \\
& $-0.003^{* *}$ & -0.003 & -0.003 \\
Float & $(-1.97)$ & $(-1.40)$ & $(-1.45)$ \\
& $-0.004^{* *}$ & $-0.004^{*}$ & $-0.003^{* *}$ \\
Ret & $(-2.14)$ & $(-1.86)$ & $(-2.24)$ \\
& -0.834 & -0.709 & -0.574 \\
Residual_SPT & $(-1.25)$ & $(-1.21)$ & $(-0.81)$ \\
Residual_INST & $3.324^{* *}$ & $3.664^{*}$ & $3.744^{* *}$ \\
& $(1.96)$ & $(1.90)$ & $(2.04)$ \\
Residual_SPT $\times I N S T$ & $0.473^{*}$ & 0.242 & 0.249 \\
& $(1.74)$ & $(1.21)$ & $(1.10)$ \\
Observation & $-1.280^{* *}$ & $-1.363^{* * *}$ & $-1.079^{* *}$ \\
Fixed Effects & $(-2.35)$ & $(-2.64)$ & $(-2.03)$ \\
\hline
\end{tabular}

Panel B: Probability of issuing a management Forecast

\begin{tabular}{cccc}
\hline Variable & Bandwidth: 200 & Bandwidth: 250 & Bandwidth: 300 \\
\hline SPT & $-4.832^{*}$ & $-5.388^{* *}$ & $-5.975^{* *}$ \\
SPT $\times I N S T$ & $(-1.73)$ & $(-2.44)$ & $(-2.23)$ \\
INST & $2.064^{* * *}$ & $2.088^{* * *}$ & $2.058^{* * *}$ \\
& $(2.56)$ & $(2.87)$ & $(3.31)$ \\
Lnmv & -0.352 & 0.014 & -0.012 \\
& $(-1.01)$ & $(0.05)$ & $(-0.05)$ \\
Rank & -2.706 & -2.033 & -1.808 \\
& $(-1.21)$ & $(-1.11)$ & $(-1.14)$ \\
Float & -0.004 & -0.003 & -0.002 \\
& $(-1.26)$ & $(-0.99)$ & $(-0.76)$ \\
Ret & -0.005 & -0.004 & -0.004 \\
& $(-1.41)$ & $(-1.52)$ & $(-1.48)$ \\
Residual_SPT & -1.322 & -1.195 & -0.923 \\
& $(-1.28)$ & $(-1.29)$ & $(-0.92)$ \\
Residual_INST & $5.023^{*}$ & $5.586^{* *}$ & $6.133^{* *}$ \\
Residual_SPT $\times I N S T$ & $(1.79)$ & $(2.53)$ & $(2.28)$ \\
& $0.626^{*}$ & 0.259 & 0.253 \\
Observation & $(1.81)$ & $(0.83)$ & $(0.96)$ \\
Fixed Effects & $-2.015^{* * *}$ & $-2.062^{* * *}$ & -2.006 \\
& $(-2.51)$ & $(-2.86)$ & $(-3.25)$ \\
& 2,693 & 3,376 & 4,052 \\
& Year & Year & Year \\
\hline
\end{tabular}


Panel A presents the estimates of the effect of speculation (SPT) on the frequency of management forecasts (FREQ). Panel B of Table 5 presents the estimates of the effect of speculation $(S P T)$ on the probability of issuing a management forecast $(P R O B)$. The models are estimated over the 1996-2006 period using bandwidths of 200, 250 and 300 firms around the Russell 1000/2000 threshold. We report estimates with t-statistics in parentheses. Bootstrapped standard errors are used to calculate $t$ statistics. Variables are defined in Appendix A. *,**, and *** indicate significance at the $10 \%, 5 \%$, and $1 \%$ level, respectively. 
Table 5: The joint effect of speculation and short-sale constraints on precision of earnings forecasts

Panel A: Linear model

\begin{tabular}{|c|c|c|c|}
\hline Variable & Bandwidth: 200 & Bandwidth: 250 & Bandwidth: 300 \\
\hline$S P T$ & $\begin{array}{c}-2.501 * * \\
(-2.12)\end{array}$ & $\begin{array}{c}-2.516^{* *} \\
(-1.96)\end{array}$ & $\begin{array}{c}-3.223 * * \\
(-2.35)\end{array}$ \\
\hline$S P T \times I N S T$ & $\begin{array}{c}1.267 * * * \\
(3.84)\end{array}$ & $\begin{array}{c}1.291 * * * \\
(4.26)\end{array}$ & $\begin{array}{c}1.423 * * * \\
(4.78)\end{array}$ \\
\hline INST & $\begin{array}{l}5.000 \\
(1.44)\end{array}$ & $\begin{array}{l}0.428 \\
(0.30)\end{array}$ & $\begin{array}{l}0.669 \\
(0.62)\end{array}$ \\
\hline Lnmv & $\begin{array}{l}6.942 \\
(1.05)\end{array}$ & $\begin{array}{l}-2.213 \\
(-0.09)\end{array}$ & $\begin{array}{l}0.202 \\
(0.12)\end{array}$ \\
\hline Float & $\begin{array}{l}0.005 \\
(1.00)\end{array}$ & $\begin{array}{l}-0.001 \\
(-0.60)\end{array}$ & $\begin{array}{l}-0.001 \\
(-0.61)\end{array}$ \\
\hline Rank & $\begin{array}{l}0.007 \\
(1.16)\end{array}$ & $\begin{array}{l}-0.001 \\
(-0.19)\end{array}$ & $\begin{array}{c}0.0005 \\
(0.22)\end{array}$ \\
\hline Ret & $\begin{array}{l}-0.627 \\
(-0.93)\end{array}$ & $\begin{array}{l}-0.681 \\
(-0.42)\end{array}$ & $\begin{array}{l}-0.608 \\
(-0.18)\end{array}$ \\
\hline Residual_SPT & $\begin{array}{c}2.592 * * \\
(2.20)\end{array}$ & $\begin{array}{c}2.567 * * \\
(1.98)\end{array}$ & $\begin{array}{c}3.311 * * * \\
(2.41)\end{array}$ \\
\hline Residual_INST & $\begin{array}{l}-4.859 \\
(-1.40)\end{array}$ & $\begin{array}{l}-0.284 \\
(-0.20)\end{array}$ & $\begin{array}{l}-0.555 \\
(-0.52)\end{array}$ \\
\hline Residual_SPT $\times I N S T$ & $\begin{array}{c}-1.258 * * * \\
(-3.71)\end{array}$ & $\begin{array}{c}-1.281 * * * \\
(-4.12)\end{array}$ & $\begin{array}{c}-1.403 * * * \\
(--4.55)\end{array}$ \\
\hline Observation & 2,890 & 3,618 & 4,328 \\
\hline Fixed Effects & Year & Year & Year \\
\hline \multicolumn{4}{|c|}{ Panel B: Ordinal logit model } \\
\hline Variable & Bandwidth: 200 & Bandwidth: 250 & Bandwidth: 300 \\
\hline$S P T$ & $\begin{array}{c}-4.382^{*} \\
(-1.88)\end{array}$ & $\begin{array}{c}-4.868 * * \\
(-2.54)\end{array}$ & $\begin{array}{c}-6.105 * * * \\
(-2.86)\end{array}$ \\
\hline$S P T \times I N S T$ & $\begin{array}{c}2.120 * * * \\
(3.11)\end{array}$ & $\begin{array}{c}2.331 * * * \\
(3.37)\end{array}$ & $\begin{array}{c}2.599 * * * \\
(4.56)\end{array}$ \\
\hline$I N S T$ & $\begin{array}{c}8.918 * * * \\
(2.83)\end{array}$ & $\begin{array}{l}1.247 \\
(0.30)\end{array}$ & $\begin{array}{l}1.426 \\
(0.40)\end{array}$ \\
\hline$L n m v$ & $\begin{array}{c}11.231^{*} \\
(1.76)\end{array}$ & $\begin{array}{l}-0.880 \\
(-0.10)\end{array}$ & $\begin{array}{l}-0.664 \\
(-0.26)\end{array}$ \\
\hline Float & $\begin{array}{l}0.007 \\
(1.06)\end{array}$ & $\begin{array}{c}-0.004 \\
(--0.40)\end{array}$ & $\begin{array}{l}-0.004 \\
(-1.43)\end{array}$ \\
\hline Rank & $\begin{array}{l}0.009 \\
(1.54)\end{array}$ & $\begin{array}{l}-0.002 \\
(-0.49)\end{array}$ & $\begin{array}{l}-0.001 \\
(-0.22)\end{array}$ \\
\hline Ret & $\begin{array}{l}-1.304 \\
(-1.21)\end{array}$ & $\begin{array}{l}-1.345 \\
(-1.12)\end{array}$ & $\begin{array}{l}-1.194 \\
(-1.14)\end{array}$ \\
\hline Residual_SPT & $\begin{array}{l}4.507^{*} \\
(1.93)\end{array}$ & $\begin{array}{c}4.988 * * * \\
(2.60)\end{array}$ & $\begin{array}{l}6.200 * * * \\
(2.90)\end{array}$ \\
\hline Residual_INST & $\begin{array}{c}-8.659 * * * \\
(-2.75)\end{array}$ & $\begin{array}{l}-0.978 \\
(-0.24)\end{array}$ & $\begin{array}{l}-1.224 \\
(-0.34)\end{array}$ \\
\hline Residual_SPT $\times I N S T$ & $\begin{array}{c}-2.093 * * * \\
(-3.04)\end{array}$ & $\begin{array}{c}-2.304 * * * \\
(-3.29)\end{array}$ & $\begin{array}{c}-2.523 * * * \\
(-4.40)\end{array}$ \\
\hline Observation & 2,890 & 3,618 & 4,328 \\
\hline Fixed Effects & Year & Year & Year \\
\hline
\end{tabular}


This table presents the estimates of the effect of speculation (SPT) on the specificity of earnings forecasts (Precision). Panel A shows the results of the linear model. Panel B shows the results of the ordinal logit model. The models are estimated over the 1996-2006 period using bandwidths of 200, 250 and 300 firms around the Russell 1000/2000 threshold. We report estimates with t-statistics in parentheses. Bootstrapped standard errors are used to calculate $t$ statistics. Variables are defined in Appendix A. *,**, and *** indicate significance at the $10 \%, 5 \%$, and $1 \%$ level, respectively 
Table 6: The effect of equity incentives on the relationship between speculation and management forecasts

\begin{tabular}{|c|c|c|c|}
\hline \multicolumn{2}{|c|}{ Bandwidth: 200} & Bandwidth: 250 & Bandwidth: 300 \\
\hline \multicolumn{4}{|c|}{ Panel A: Frequency of management forecasts } \\
\hline \multirow[b]{2}{*}{$S P T$} & Estimator & Estimator & Estimator \\
\hline & $\begin{array}{l}-1.317 \\
(-0.63)\end{array}$ & $\begin{array}{l}-1.687 \\
(-0.52)\end{array}$ & $\begin{array}{l}-2.509 \\
(-0.32)\end{array}$ \\
\hline$S P T \times I N S T$ & $\begin{array}{l}1.198 \\
(0.78)\end{array}$ & $\begin{array}{l}1.202 \\
(0.99)\end{array}$ & $\begin{array}{l}1.497 \\
(1.06)\end{array}$ \\
\hline$S T C O M P \times S P T \times I N S T$ & $\begin{array}{l}0.076 \\
(1.42)\end{array}$ & $\begin{array}{c}0.098 * * \\
(2.08)\end{array}$ & $\begin{array}{c}0.117 * * \\
(2.25)\end{array}$ \\
\hline$S T C O M P \times S P T$ & $\begin{array}{l}0.009 \\
(0.13)\end{array}$ & $\begin{array}{l}0.016 \\
(0.26)\end{array}$ & $\begin{array}{l}0.040 \\
(0.62)\end{array}$ \\
\hline STCOMP & $\begin{array}{l}-0.124 \\
(-1.09)\end{array}$ & $\begin{array}{l}-0.015 \\
(-0.14)\end{array}$ & $\begin{array}{l}-0.094 \\
(-0.22)\end{array}$ \\
\hline Observation & 1,642 & 2,078 & 2,531 \\
\hline \multicolumn{4}{|c|}{ Panel B: Probability of issuing a management forecast } \\
\hline \multirow[b]{2}{*}{$S P T$} & Estimator & Estimator & Estimator \\
\hline & $\begin{array}{l}-3.831 \\
(-0.89)\end{array}$ & $\begin{array}{l}-3.943 \\
(-0.51)\end{array}$ & $\begin{array}{c}-5.126^{* *} \\
(-0.14)\end{array}$ \\
\hline$S P T \times I N S T$ & $\begin{array}{l}3.190 \\
(1.29)\end{array}$ & $\begin{array}{l}2.798 \\
(1.61)\end{array}$ & $\begin{array}{c}3.189^{*} \\
(1.87)\end{array}$ \\
\hline$S T C O M P \times S P T \times I N S T$ & $\begin{array}{l}0.131 \\
(1.14)\end{array}$ & $\begin{array}{l}0.168 * \\
(1.68)\end{array}$ & $\begin{array}{c}0.189 * * \\
(1.97)\end{array}$ \\
\hline$S T C O M P \times S P T$ & $\begin{array}{l}0.115 \\
(1.11)\end{array}$ & $\begin{array}{l}0.125 \\
(1.61)\end{array}$ & $\begin{array}{l}0.126 \\
(1.24)\end{array}$ \\
\hline STCOMP & $\begin{array}{c}-0.424 * * \\
(-2.22)\end{array}$ & $\begin{array}{l}-0.232 \\
(-1.07)\end{array}$ & $\begin{array}{l}-0.286 \\
(-0.20)\end{array}$ \\
\hline Observation & 1,642 & 1,987 & 2,531 \\
\hline \multicolumn{4}{|c|}{ Panel C: Precision of earnings forecasts } \\
\hline & Estimator & Estimator & Estimator \\
\hline$S P T$ & $\begin{array}{l}-1.049 \\
(-0.19)\end{array}$ & $\begin{array}{l}-0.789 \\
(-0.51)\end{array}$ & $\begin{array}{l}-2.059 \\
(-1.02)\end{array}$ \\
\hline$S P T \times I N S T$ & $\begin{array}{c}2.151^{* *} \\
(2.48)\end{array}$ & $\begin{array}{c}1.877 * * * \\
(2.61)\end{array}$ & $\begin{array}{c}2.512 * * * \\
(3.01)\end{array}$ \\
\hline$S T C O M P \times S P T \times I N S T$ & $\begin{array}{c}0.119 * * \\
(2.40)\end{array}$ & $\begin{array}{c}0.108 * * * \\
(2.97)\end{array}$ & $\begin{array}{c}0.118 * * * \\
(3.02)\end{array}$ \\
\hline$S T C O M P \times S P T$ & $\begin{array}{l}0.004 \\
(0.10)\end{array}$ & $\begin{array}{l}0.023 \\
(0.57)\end{array}$ & $\begin{array}{l}0.040 \\
(1.14)\end{array}$ \\
\hline STCOMP & $\begin{array}{l}0.016 \\
(0.01)\end{array}$ & $\begin{array}{l}-0.080 \\
(-0.04)\end{array}$ & $\begin{array}{l}-0.062 \\
(-0.04)\end{array}$ \\
\hline Observation & 1,859 & 2,345 & 2,839 \\
\hline
\end{tabular}

This table presents the estimates of the effect of equity incentives on the relationship between disagreementbased speculation (SPT) and FREQ, PROB and Precision. We include STComp, SPT* STComp, INST* STComp, and SPT* STComp*INST in the Eq. (10). The models are estimated over the 1996-2006 period using bandwidths of 200, 250 and 300 firms around the Russell 1000/2000 threshold. We only report the variables of interest for brevity. We report estimates with t-statistics in parentheses. Bootstrapped standard errors are used to calculate t statistics. Variables are defined in Appendix A. *, **, and *** indicate significance at the $10 \%, 5 \%$, and $1 \%$ level, respectively. Each regression includes year fixed effects. 
Table 7: The joint effect of speculation and short-sale constraints on insider trading

\begin{tabular}{cccc}
\hline Variable & Bandwidth: 200 & Bandwidth: 250 & Bandwidth: 300 \\
\hline SPT & $3.197^{* * *}$ & $3.603^{* *}$ & $3.866^{* *}$ \\
SPT $\times I N S T$ & $(2.42)$ & $(2.05)$ & $(1.98)$ \\
& $-1.188^{* *}$ & $-1.091^{*}$ & $-1.081^{*}$ \\
INST & $(-1.96)$ & $(-1.95)$ & $(-1.89)$ \\
& 0.054 & 0.066 & 0.014 \\
Lnmv & $(0.20)$ & $(0.27)$ & $(0.06)$ \\
& -1.151 & -1.485 & $-1.912^{*}$ \\
Float & $(-1.53)$ & $(-1.64)$ & $(-2.16)$ \\
& -0.001 & -0.001 & $-0.001^{*}$ \\
Rank & $(-0.79)$ & $(-0.98)$ & $(-1.60)$ \\
& -0.002 & $-0.003^{* *}$ & $-0.002^{* *}$ \\
Ret & $(-1.47)$ & $(-1.98)$ & $(-2.50)$ \\
& $1.825^{* * *}$ & $1.736^{* * *}$ & $1.585^{* *}$ \\
$R \_S P T$ & $(2.84)$ & $(2.89)$ & $(2.35)$ \\
& $-2.772^{* * *}$ & $-3.164^{* *}$ & $-3.466^{*}$ \\
$R \_I N S T$ & $(-2.09)$ & $(-2.33)$ & $(-1.76)$ \\
& 0.327 & 0.308 & 0.390 \\
$R$ SPT $\times I N S T$ & $(1.05)$ & $(1.22)$ & $(1.49)$ \\
& $1.098^{* *}$ & $1.028^{*}$ & $0.984^{*}$ \\
Observation & $(2.07)$ & $(1.86)$ & $(1.73)$ \\
Fixed Effects & 2,693 & 3,376 & 4,052 \\
\hline
\end{tabular}

This table presents the estimates of the effect of speculation (SPT) on the probability of selling shares by managers (Insidersell). The models are estimated over the 1996-2006 period using bandwidths of 200, 250 and 300 firms around the Russell 1000/2000 threshold. We report estimates with t-statistics in parentheses. Bootstrapped standard errors are used to calculate $t$ statistics. Variables are defined in Appendix A. *, **, and $* * *$ indicate significance at the $10 \%, 5 \%$, and $1 \%$ level, respectively. 
Table 8: The joint effect of speculation and short-sale constraints on optimism of earnings forecasts

\begin{tabular}{cccc}
\hline Variable & Bandwidth: 200 & Bandwidth: 250 & Bandwidth: 300 \\
\hline SPT & $4.467^{*}$ & $5.189^{* * *}$ & $4.682^{* *}$ \\
SPT $\times$ INST & $(1.80)$ & $(2.33)$ & $(2.15)$ \\
& $-1.689^{* *}$ & $-1.837^{* *}$ & $-1.701^{* *}$ \\
INST & $(-2.13)$ & $(-2.06)$ & $(-2.24)$ \\
& 0.357 & 0.666 & 0.576 \\
Lnmv & $(0.72)$ & $(1.51)$ & $(1.48)$ \\
& 1.169 & 1.407 & -0.029 \\
Float & $(0.56)$ & $(0.76)$ & $(-0.02)$ \\
& 0.003 & 0.003 & 0.0003 \\
Rank & $(1.03)$ & $(1.10)$ & $(0.15)$ \\
& 0.002 & 0.002 & -0.0003 \\
Ret & $(0.62)$ & $(0.60)$ & $(-0.16)$ \\
& $1.920^{* *}$ & $2.547^{* * *}$ & $2.405^{* * *}$ \\
R_SPT & $(2.10)$ & $(2.88)$ & $(3.50)$ \\
& $-4.317^{*}$ & $-5.085^{* *}$ & $-4.618^{* *}$ \\
R_INST & $(-1.74)$ & $(-2.30)$ & $(-2.11)$ \\
& -0.242 & -0.560 & -0.454 \\
$R \_S P T \times I N S T$ & $(-0.49)$ & $(-1.27)$ & $(-1.20)$ \\
InverseMills & $1.770^{* *}$ & $1.905^{* *}$ & $1.803^{* *}$ \\
& $(2.24)$ & $(2.18)$ & $(2.39)$ \\
Observation & $-1.600^{* * *}$ & $-1.658^{* * *}$ & $-1.698^{* * *}$ \\
Fixed Effects & $(9.49)$ & $(-10.73)$ & $(-12.47)$ \\
\hline
\end{tabular}

This table presents the estimates of the effect of speculation (SPT) on the probability of issuing good news (Goodnews). The models are estimated over the 1996-2006 period using bandwidths of 200, 250 and 300 firms around the Russell 1000/2000 threshold. We report estimates with t-statistics in parentheses. Bootstrapped standard errors are used to calculate t statistics. Variables are defined in Appendix A. *, **, and *** indicate significance at the $10 \%, 5 \%$, and $1 \%$ level, respectively. 
Table 9: The joint effect of speculation and short-sale constraints on cumulative excess returns around forecast dates

\begin{tabular}{cccc}
\hline Variable & Bandwidth: 200 & Bandwidth: 250 & Bandwidth: 300 \\
\hline \multirow{2}{*}{$S P T$} & -0.251 & -0.312 & -0.288 \\
& $(-0.08)$ & $(-1.23)$ & $(-0.44)$ \\
$S P T \times I N S T$ & $0.109^{*}$ & $0.134^{* *}$ & $0.111^{*}$ \\
& $(1.78)$ & $(2.12)$ & $(1.85)$ \\
INST & 0.0004 & -0.002 & 0.003 \\
& $(-0.01)$ & $(-0.06)$ & $(0.74)$ \\
Lnmv & 0.719 & 0.102 & 0.127 \\
& $(0.08)$ & $(0.68)$ & $(0.66)$ \\
Float & -0.0001 & 0.0001 & 0.0001 \\
& $(-0.14)$ & $(0.38)$ & $0.19)$ \\
Rank & 0.0004 & 0.0001 & 0.0001 \\
& $(-0.03)$ & $(0.31)$ & $(0.46)$ \\
$R \_S P T$ & 0.229 & 0.288 & 0.263 \\
& $(0.14)$ & $(1.19)$ & $(0.40)$ \\
$R \_I N S T$ & 0.008 & 0.008 & 0.003 \\
& $(0.23)$ & $(0.08)$ & $(0.21)$ \\
$R \_S P T \times I N S T$ & $-0.111^{*}$ & $-0.128^{* *}$ & $-0.103 *$ \\
Observation & $(-1.72)$ & $(-2.01)$ & $(-1.73)$ \\
Fixed Effects & 1,305 & 1,892 & 1,939 \\
\hline
\end{tabular}

This table presents estimates of the effects of speculation $(S P T)$ on three-day cumulative excess returns around management forecast dates $(C A R)$. We select management forecasts issued in September and October of each respective year. The models are estimated over the 1996-2006 period using bandwidths of 200, 250 and 300 firms around the Russell 1000/2000 threshold. We report estimates with t-statistics in parentheses. Bootstrapped standard errors are used to calculate t statistics. Variables are defined in Appendix A. *, **, and *** indicate significance at the $10 \%, 5 \%$, and $1 \%$ level, respectively. 


\section{Table 10: Robustness test using regulation SHO}

\begin{tabular}{|c|c|c|c|c|c|c|c|c|c|}
\hline \multirow[b]{2}{*}{ Variable } & \multicolumn{3}{|c|}{ Bandwidth: 200} & \multicolumn{3}{|c|}{ Bandwidth: 250} & \multicolumn{3}{|c|}{ Bandwidth: 300} \\
\hline & FREQ & $P R O B$ & Precision & FREQ & $P R O B$ & Precision & FREQ & $P R O B$ & Precision \\
\hline$S P T$ & $\begin{array}{c}-1.753 * * \\
(-1.98)\end{array}$ & $\begin{array}{c}-2.428 * \\
(-1.69)\end{array}$ & $\begin{array}{c}-4.884 * * * \\
(-4.00)\end{array}$ & $\begin{array}{c}-1.291 * \\
(-1.68)\end{array}$ & $\begin{array}{c}-2.275^{*} \\
(-1.82)\end{array}$ & $\begin{array}{c}-3.430 * * * \\
(-4.38)\end{array}$ & $\begin{array}{c}-1.336^{*} \\
(-1.65)\end{array}$ & $\begin{array}{c}-2.308 * * \\
(-2.02)\end{array}$ & $\begin{array}{c}-2.948 * * * \\
(-3.26)\end{array}$ \\
\hline$S P T \times S H O$ & $\begin{array}{c}0.448^{* * *} \\
(2.88)\end{array}$ & $\begin{array}{c}0.741 * * \\
(2.30)\end{array}$ & $\begin{array}{c}0.234 \\
(1.36)\end{array}$ & $\begin{array}{l}0.291 * \\
(1.81)\end{array}$ & $\begin{array}{c}0.633^{* *} \\
(2.38)\end{array}$ & $\begin{array}{l}0.144 \\
(0.96)\end{array}$ & $\begin{array}{c}0.305 * * \\
(2.16)\end{array}$ & $\begin{array}{c}0.697 * * * \\
(2.80)\end{array}$ & $\begin{array}{c}0.237^{*} \\
(1.80)\end{array}$ \\
\hline $\mathrm{SHO}$ & $\begin{array}{l}-0.228 \\
(-1.59)\end{array}$ & $\begin{array}{c}-0.387 * \\
(-1.94)\end{array}$ & $\begin{array}{l}0.267 \\
(1.49)\end{array}$ & $\begin{array}{l}-0.192 \\
(-1.42)\end{array}$ & $\begin{array}{c}-0.430^{* *} \\
(-2.37)\end{array}$ & $\begin{array}{l}0.024 \\
(0.04)\end{array}$ & $\begin{array}{l}-0.187 \\
(-1.57)\end{array}$ & $\begin{array}{c}-0.424 * * * \\
(-2.80)\end{array}$ & $\begin{array}{l}-0.305 \\
(-0.99)\end{array}$ \\
\hline$L n m v$ & $\begin{array}{c}-6.058 * * * \\
(-3.10)\end{array}$ & $\begin{array}{c}-8.348 * * * \\
(-3.55)\end{array}$ & $\begin{array}{c}-10.70 * * * \\
(-4.02)\end{array}$ & $\begin{array}{c}-5.196 * * * \\
(-2.79)\end{array}$ & $\begin{array}{c}-7.378 * * * \\
(-3.33)\end{array}$ & $\begin{array}{l}-8.499 \\
(-0.66)\end{array}$ & $\begin{array}{c}-5.242 * * * \\
(-3.20)\end{array}$ & $\begin{array}{c}-7.990 * * * \\
(-4.15)\end{array}$ & $\begin{array}{l}-0.877 \\
(-0.15)\end{array}$ \\
\hline Rank & $\begin{array}{c}-0.008 * * * \\
(-3.47)\end{array}$ & $\begin{array}{c}-0.011 * * * \\
(-3.80)\end{array}$ & $\begin{array}{c}-0.012 * * * \\
(-4.65)\end{array}$ & $\begin{array}{c}-0.007 * * * \\
(-2.95)\end{array}$ & $\begin{array}{c}-0.011 * * * \\
(-3.58)\end{array}$ & $\begin{array}{l}-0.010 \\
(-0.90)\end{array}$ & $\begin{array}{c}-0.007 * * * \\
(-3.27)\end{array}$ & $\begin{array}{c}-0.011 * * * \\
(-3.76)\end{array}$ & $\begin{array}{l}-0.003 \\
(-0.52)\end{array}$ \\
\hline Float & $\begin{array}{c}-0.009 * * * \\
(-3.63)\end{array}$ & $\begin{array}{c}-0.012 * * * \\
(-3.50)\end{array}$ & $\begin{array}{c}-0.011 * * * \\
(-3.80)\end{array}$ & $\begin{array}{c}-0.008 * * * \\
(-3.40)\end{array}$ & $\begin{array}{c}-0.011 * * * \\
(-3.86)\end{array}$ & $\begin{array}{c}0.001 * * * \\
(-3.16)\end{array}$ & $\begin{array}{c}-0.007 * * * \\
(-3.41)\end{array}$ & $\begin{array}{c}-0.011 * * * \\
(-3.94)\end{array}$ & $\begin{array}{c}-0.006 * * * \\
(-3.43)\end{array}$ \\
\hline$I N S T$ & $\begin{array}{l}-0.244 \\
(-0.62)\end{array}$ & $\begin{array}{l}-2.367 \\
(-0.93)\end{array}$ & $\begin{array}{l}-2.975 \\
(-1.44)\end{array}$ & $\begin{array}{l}-0.383 \\
(-0.80)\end{array}$ & $\begin{array}{l}-0.332 \\
(-0.12)\end{array}$ & $\begin{array}{l}-1.940 \\
(-0.22)\end{array}$ & $\begin{array}{l}-1.934 \\
(-1.12)\end{array}$ & $\begin{array}{l}-2.437 \\
(-0.94)\end{array}$ & $\begin{array}{l}2.590 \\
(0.63)\end{array}$ \\
\hline Ret & $\begin{array}{c}-1.414^{* *} \\
(-2.24)\end{array}$ & $\begin{array}{c}-1.724^{*} \\
(-1.66)\end{array}$ & $\begin{array}{c}-5.513 * * * \\
(3.70)\end{array}$ & $\begin{array}{l}-0.383 \\
(-0.33)\end{array}$ & $\begin{array}{l}-0.637 \\
(-0.82)\end{array}$ & $\begin{array}{l}1.691 \\
(-0.96)\end{array}$ & $\begin{array}{l}-0.107 \\
(-0.22)\end{array}$ & $\begin{array}{l}-0.061 \\
(-0.09)\end{array}$ & $\begin{array}{l}-2.389 \\
(-1.63)\end{array}$ \\
\hline$R \_S P T$ & $\begin{array}{c}1.953 * * \\
(2.22)\end{array}$ & $\begin{array}{c}2.725^{*} \\
(1.89)\end{array}$ & $\begin{array}{c}5.031 * * * \\
(4.12)\end{array}$ & $\begin{array}{c}1.546^{* *} \\
(2.03)\end{array}$ & $\begin{array}{c}2.565 * * \\
(2.07)\end{array}$ & $\begin{array}{c}3.626^{* * *} \\
(3.55)\end{array}$ & $\begin{array}{c}1.577 * * \\
(1.98)\end{array}$ & $\begin{array}{c}2.581 * * \\
(2.25)\end{array}$ & $\begin{array}{c}3.139 * * * \\
(3.46)\end{array}$ \\
\hline$R \_I N S T$ & $\begin{array}{l}2.551 \\
(1.36)\end{array}$ & $\begin{array}{c}5.038 * * \\
(1.98)\end{array}$ & $\begin{array}{l}3.387 \\
(1.64)\end{array}$ & $\begin{array}{l}2.203 \\
(1.11)\end{array}$ & $\begin{array}{l}2.930 \\
(1.10)\end{array}$ & $\begin{array}{l}2.363 \\
(0.26)\end{array}$ & $\begin{array}{c}3.637 * * \\
(2.15)\end{array}$ & $\begin{array}{c}4.484^{*} \\
(1.89)\end{array}$ & $\begin{array}{l}-2.215 \\
(-0.54)\end{array}$ \\
\hline Observation & 876 & 876 & 926 & 1,111 & 1,111 & 1,185 & 1,340 & 1,340 & 1,423 \\
\hline Fixed Effects & Year & Year & Year & Year & Year & Year & Year & Year & Year \\
\hline
\end{tabular}

This table presents estimates of the effects of speculation (SPT) on FREQ, PROB and Precision using an alternative measure of short-sale constraints. In July 2004, the SEC approved Rule 202T, which established a pilot program to study the effect of short-sale constraints on the price formation process. The program selects a random sample for 968 Russell 3000 firms for which the short sale uptick rule is suspended from 2005 to 2007 . We set SHO to 1 for these firms and 0 for the remaining firms. The model is estimated over the 2004-2006 period using the bandwidth of 300 firms around the Russell 1000/2000 threshold. We report estimates with t-statistics in parentheses. Bootstrapped standard errors are used to calculate $t$ statistics. Variables are defined in Appendix A. *,**, and *** indicate significance at the $10 \%, 5 \%$, and $1 \%$ level, respectively. 
Table 11: The joint effect of speculation and short-sale constraints on management forecasts after controlling for analyst coverage

\begin{tabular}{|c|c|c|c|}
\hline \multicolumn{2}{|c|}{ Bandwidth: 200} & Bandwidth: 250 & Bandwidth: 300 \\
\hline \multicolumn{4}{|c|}{ Panel A. Frequency of management forecasts } \\
\hline \multirow{3}{*}{$S P T$} & Estimator & Estimator & Estimator \\
\hline & $-2.557 * *$ & $-2.598 * *$ & $-2.775^{* *}$ \\
\hline & $(-2.44)$ & $(-2.34$ & $(-2.36)$ \\
\hline \multirow{2}{*}{$S P T \times I N S T$} & $1.153^{* *}$ & 1.079 & 0.858 \\
\hline & $(2.05)$ & $\left(2.19^{* *}\right)$ & $(1.74 *)$ \\
\hline \multirow{2}{*}{ INST } & 0.018 & 0.186 & 0.152 \\
\hline & $(0.09)$ & $(0.89)$ & $(0.79)$ \\
\hline \multirow{2}{*}{ Coverage } & $0.048 * * *$ & 0.044 & 0.043 \\
\hline & $(5.83)$ & $(5.45)^{* * *}$ & $(5.87 * * *)$ \\
\hline Observation & 2,458 & 3,086 & 3,690 \\
\hline \multicolumn{4}{|c|}{ Panel B. Probability of issuing a management forecast } \\
\hline \multirow{3}{*}{$S P T$} & Estimator & Estimator & Estimator \\
\hline & $-3.151 * *$ & $-3.49 * *$ & $-4.248 * *$ \\
\hline & $(-2.25)$ & $(-2.27)$ & $(-2.44)$ \\
\hline \multirow[t]{2}{*}{$S P T \times I N S T$} & $1.508^{* *}$ & $1.397 * *$ & $1.514 * *$ \\
\hline & $(2.05)$ & $(2.01)$ & $(2.22)$ \\
\hline \multirow[t]{2}{*}{ INST } & 0.272 & $0.508^{*}$ & $0.419^{*}$ \\
\hline & $(0.92)$ & $(1.92)$ & (1.68) \\
\hline \multirow{2}{*}{ Coverage } & $0.085^{* * *}$ & $0.069 * * *$ & $0.064 * * *$ \\
\hline & $(6.09)$ & $(6.18)$ & $(6.04)$ \\
\hline Observation & 2,458 & 3,086 & 3,693 \\
\hline \multicolumn{4}{|c|}{ Panel C. Precision of earnings forecasts } \\
\hline \multirow{3}{*}{$S P T$} & Estimator & Estimator & Estimator \\
\hline & $-2.135 * * *$ & $-2.189 * * *$ & $-2.958 * * *$ \\
\hline & $(-3.32)$ & $(-3.33)$ & $(-3.97)$ \\
\hline \multirow[t]{2}{*}{$S P T \times I N S T$} & $1.180 * * *$ & $1.173 * * *$ & $1.351 * * *$ \\
\hline & (3.69) & (3.93) & $(4.61)$ \\
\hline \multirow[t]{2}{*}{ INST } & 3.751 & 0.202 & 0.428 \\
\hline & $(1.03)$ & $(0.15)$ & $(0.39)$ \\
\hline \multirow{2}{*}{ Coverage } & $0.040 * * *$ & $0.033 * * *$ & $0.029 * * *$ \\
\hline & $(5.68)$ & $(5.42)$ & $(5.51)$ \\
\hline Observation & 2,672 & 3,339 & 3,986 \\
\hline
\end{tabular}

This table presents the estimates of the effect of speculation (SPT) on FREQ, PROB and Precision after we control for contemporaneous analyst coverage (Coverage). We only report the variables of interest for brevity. The models are estimated over the 1996-2006 period using bandwidths of 200, 250 and 300 firms around the Russell 1000/2000 threshold. We report estimates with t-statistics in parentheses. Bootstrapped standard errors are used to calculate $t$ statistics. Variables are defined in Appendix A. *,**, and *** indicate significance at the $10 \%, 5 \%$, and $1 \%$ level, respectively. Each regression includes year fixed effects. 
Table 12: Alternative model specification

\begin{tabular}{|c|c|c|c|c|c|c|c|c|c|}
\hline \multirow[b]{2}{*}{ Variable } & \multicolumn{3}{|c|}{ Bandwidth: 200} & \multicolumn{3}{|c|}{ Bandwidth: 250} & \multicolumn{3}{|c|}{ Bandwidth: 300} \\
\hline & FREQ & $P R O B$ & Precision & $F R E Q$ & $P R O B$ & Precision & FREQ & $P R O B$ & Precision \\
\hline$S P T$ & $\begin{array}{c}-6.205 * * \\
(-2.11)\end{array}$ & $\begin{array}{c}-9.128 * * \\
(-2.55)\end{array}$ & $\begin{array}{c}-6.091 * * * \\
(-3.33)\end{array}$ & $\begin{array}{c}-3.457 * \\
(-1.75)\end{array}$ & $\begin{array}{c}-5.784 * * \\
(-2.42)\end{array}$ & $\begin{array}{c}-4.028 * * \\
(-2.58)\end{array}$ & $\begin{array}{c}-2.705^{*} \\
(-1.73)\end{array}$ & $\begin{array}{c}-5.186^{* * *} \\
(-2.83)\end{array}$ & $\begin{array}{c}-3.553 * * * \\
(-3.32)\end{array}$ \\
\hline$S P T \times I N S T$ & $\begin{array}{l}1.572^{*} \\
(1.73)\end{array}$ & $\begin{array}{c}2.610 * * \\
(2.17)\end{array}$ & $\begin{array}{c}1.433 * * * \\
(2.89)\end{array}$ & $\begin{array}{l}1.175 \\
(1.37)\end{array}$ & $\begin{array}{c}2.081 * * \\
(2.03)\end{array}$ & $\begin{array}{c}1.197 * * \\
(2.34)\end{array}$ & $\begin{array}{l}0.809 \\
(1.18)\end{array}$ & $\begin{array}{c}1.726^{* *} \\
(2.08)\end{array}$ & $\begin{array}{c}0.973 * * \\
(2.47)\end{array}$ \\
\hline$I N S T$ & $\begin{array}{l}0.281 \\
(1.05)\end{array}$ & $\begin{array}{c}0.571^{*} \\
(1.83)\end{array}$ & $\begin{array}{l}1.541 \\
(0.68)\end{array}$ & $\begin{array}{l}0.286 \\
(1.24)\end{array}$ & $\begin{array}{l}0.482 \\
(1.52)\end{array}$ & $\begin{array}{l}2.101 \\
(1.16)\end{array}$ & $\begin{array}{l}0.134 \\
(0.61)\end{array}$ & $\begin{array}{l}0.262 \\
(0.95)\end{array}$ & $\begin{array}{l}0.871 \\
(0.46)\end{array}$ \\
\hline$D^{*}($ Rank-1000) & $\begin{array}{l}-0.001 \\
(-1.12)\end{array}$ & $\begin{array}{l}-0.001 \\
(-0.82)\end{array}$ & $\begin{array}{l}-0.001 \\
(-0.64)\end{array}$ & $\begin{array}{l}-0.001 \\
(-1.44)\end{array}$ & $\begin{array}{c}-0.002 * * \\
(-2.02)\end{array}$ & $\begin{array}{c}-0.001 * \\
(-2.06)\end{array}$ & $\begin{array}{l}-0.001 \\
(-1.43)\end{array}$ & $\begin{array}{c}-0.002 * \\
(-1.79)\end{array}$ & $\begin{array}{c}-0.002 * * * \\
(-2.74)\end{array}$ \\
\hline Rank-1000 & $\begin{array}{c}0.002 * * \\
(2.25)\end{array}$ & $\begin{array}{c}0.001^{*} \\
(1.79)\end{array}$ & $\begin{array}{l}0.001 \\
(0.11)\end{array}$ & $\begin{array}{l}0.001 \\
(1.44)\end{array}$ & $\begin{array}{l}0.001 \\
(1.60)\end{array}$ & $\begin{array}{c}-0.0001 \\
(-0.24)\end{array}$ & $\begin{array}{c}0.001^{*} \\
(1.89)\end{array}$ & $\begin{array}{c}0.001 * * \\
(1.98)\end{array}$ & $\begin{array}{l}0.001 \\
(1.43)\end{array}$ \\
\hline Float & $\begin{array}{c}-0.001 * * \\
(-2.24)\end{array}$ & $\begin{array}{c}-0.002 * * * \\
(-2.58)\end{array}$ & $\begin{array}{l}-0.002 \\
(-0.94)\end{array}$ & $\begin{array}{c}-0.001 * \\
(-1.81)\end{array}$ & $\begin{array}{c}-0.001 * * \\
(2.21)\end{array}$ & $\begin{array}{l}-0.003 \\
(-1.28)\end{array}$ & $\begin{array}{l}-0.001 \\
(-1.40)\end{array}$ & $\begin{array}{c}-0.001 * \\
(-1.90)\end{array}$ & $\begin{array}{l}-0.001 \\
(-0.70)\end{array}$ \\
\hline Residual_SPT & $\begin{array}{c}6.414^{* *} \\
(2.18)\end{array}$ & $\begin{array}{c}9.364 * * * \\
(2.60)\end{array}$ & $\begin{array}{c}6.177 * * * \\
(3.40)\end{array}$ & $\begin{array}{l}3.710^{*} \\
(1.86)\end{array}$ & $\begin{array}{c}6.044 * * \\
(2.52)\end{array}$ & $\begin{array}{c}4.157 * * \\
(2.42)\end{array}$ & $\begin{array}{c}2.923^{*} \\
(1.87)\end{array}$ & $\begin{array}{c}5.398 * * \\
(2.20)\end{array}$ & $\begin{array}{c}3.664 * * * \\
(2.97)\end{array}$ \\
\hline Residual_INST & $\begin{array}{c}-0.049 \\
(-0.193)\end{array}$ & $\begin{array}{l}-0.261 \\
(-0.86)\end{array}$ & $\begin{array}{l}-1.354 \\
(-0.60)\end{array}$ & $\begin{array}{l}-0.008 \\
(-0.04)\end{array}$ & $\begin{array}{l}-0.128 \\
(-0.43)\end{array}$ & $\begin{array}{l}-1.896 \\
(-1.24)\end{array}$ & $\begin{array}{l}0.161 \\
(0.77)\end{array}$ & $\begin{array}{l}0.098 \\
(0.37)\end{array}$ & $\begin{array}{l}-0.659 \\
(-0.49)\end{array}$ \\
\hline Residual_SPT $\times I N S T$ & $\begin{array}{c}-1.584^{*} \\
(-1.68)\end{array}$ & $\begin{array}{c}-2.658 * * \\
(-2.26)\end{array}$ & $\begin{array}{c}-1.398 * * * \\
(-2.82)\end{array}$ & $\begin{array}{l}-1.209 \\
(-1.41)\end{array}$ & $\begin{array}{c}-2.134 * * \\
(-2.07)\end{array}$ & $\begin{array}{c}-1.162 * * \\
(-2.26)\end{array}$ & $\begin{array}{l}-0.835 \\
(-1.22)\end{array}$ & $\begin{array}{c}-1.774 * * \\
(-2.15)\end{array}$ & $\begin{array}{c}-0.946 * * \\
(-1.99)\end{array}$ \\
\hline $\begin{array}{l}\text { Fixed Effects } \\
\text { Observations }\end{array}$ & $\begin{array}{l}\text { Year } \\
2,735\end{array}$ & $\begin{array}{l}\text { Year } \\
2,735\end{array}$ & $\begin{array}{l}\text { Year } \\
2,957\end{array}$ & $\begin{array}{l}\text { Year } \\
3,428\end{array}$ & $\begin{array}{l}\text { Year } \\
3,428\end{array}$ & $\begin{array}{l}\text { Year } \\
3,721\end{array}$ & $\begin{array}{c}\text { Year } \\
4,123\end{array}$ & $\begin{array}{c}\text { Year } \\
4,123\end{array}$ & $\begin{array}{l}\text { Year } \\
4,429\end{array}$ \\
\hline
\end{tabular}

This table presents the results of two-stage estimation based on Eq. (13), (14), (15) and (16). We follow Crane et al. (2015) and use ranks based on the firm's market capitalization at the end of May rather than index weights. The models are estimated over the 1996-2006 period using the bandwidth of 300 firms around the Russell 1000/2000 threshold. We report estimates with t-statistics in parentheses. Bootstrapped standard errors are used to calculate $t$ statistics. Variables are defined in Appendix A. *,**, and *** indicate significance at the $10 \%, 5 \%$, and $1 \%$ level, respectively. 